Article

\title{
Cytotoxic Gold(I) Complexes with Amidophosphine Ligands Containing Thiophene Moieties
}

\author{
Helen Goitia, M. Dolores Villacampa, Antonio Laguna and M. Concepción Gimeno *(1) \\ Departamento de Química Inorgánica, Instituto de Síntesis Química y Catálisis Homogénea (ISQCH), \\ CSIC-Universidad de Zaragoza, 50009 Zaragoza, Spain; hgoitia@gmail.com (H.G.); dvilla@unizar.es (M.D.V.); \\ alaguna@unizar.es (A.L.) \\ * Correspondence: gimeno@unizar.es; Tel.: +34-976-762-291
}

Received: 14 December 2018; Accepted: 24 January 2019; Published: 29 January 2019

\begin{abstract}
A new phosphine ligand bearing a thiophene moiety, $\mathrm{C}_{4} \mathrm{H}_{3} \mathrm{SNHCOCH}_{2} \mathrm{CH}_{2} \mathrm{PPh}_{2}$ (L), has been prepared by reaction of the aminophosphine $\mathrm{Ph}_{2} \mathrm{PCH}_{2} \mathrm{CH}_{2} \mathrm{NH}_{2}$ with thiophenecarbonylchloride in the presence of triethylamine. The coordination behavior towards gold(I), gold(III) and silver(I) species has been studied and several metal compounds of different stoichiometry have been achieved, such as [AuL $\left.\mathrm{A}_{2}\right] \mathrm{OTf},[\mathrm{AuXL}]\left(\mathrm{X}=\mathrm{Cl}, \mathrm{C}_{6} \mathrm{~F}_{5}\right)$, $\left[\mathrm{Au}\left(\mathrm{C}_{6} \mathrm{~F}_{5}\right)_{3} \mathrm{~L}\right],\left[\mathrm{AgL}_{2}\right] \mathrm{OTf}$ or $[\mathrm{Ag}(\mathrm{OTf}) \mathrm{L}]$. Additionally, the reactivity of the chloride gold(I) species with biologically relevant thiolates was explored, thus obtaining the neutral thiolate compounds [AuL(SR)] (SR = 2-thiocitosine, 2-thiolpyridine, 2-thiouracil, 2-thionicotinic acid, 2,3,4,6-tetra-6-acetyl-1-thiol- $\beta$-D-glucopyranosato or thiopurine). The antitumor activity of the compounds was measured by the MTT method in several cancer cells and the complexes exhibit excellent cytotoxic activity.
\end{abstract}

Keywords: gold; silver; amidophosphine; thiophene; cytotoxicity; cancer

\section{Introduction}

Metal complexes have received increasing interest in the development of new chemotherapeutical drugs after the great success of cisplatin and the second or third generation drugs Carboplatin, Paraplatin and Oxaliplatin [1-3]. Platinum drugs are extensively used in cancer treatment, but the side effects and the development of platinum drug resistance on several cancer cell lines have led to research with other metallic complexes, as for example ruthenium compounds, which have been entered into clinical trials with great success [4]. Gold derivatives have been known as antiarthritic drugs for a long time, such as the well-known Auranofin. The discovery of the strong antiproliferative activity of this compound prompted to deepen in further studies about its wide biological activity, and nowadays is on clinical trials for ovarian cancer [5]. Many gold compounds, including gold(I) or gold(III) derivatives [6-9], have revealed as promising cytotoxic agents, in many cases overcoming cisplatin resistance to specific types of cancer. Additionally, they have exhibited a mechanism of action very different from that of platinum drugs. Several targets have been identified for gold complexes being the inhibition of Thioredoxin reductase one of the most important [10-12].

Five-membered aromatic rings are very important building blocks as may confer an improvement in the pharmacokinetic and pharmacodynamic drug properties. In particular, thiophene, a five-membered aromatic sulfur-containing heterocycle, is encountered in many therapeutically active agent [13], which show a number of pharmacological properties, such as antipsychotic, antidepressive, antithrombolytic, antifungal, antiviral, antiallergic, prostaglandin, dopamine receptor antagonist, and 5-lipoxygenase inhibitor [14-16]. Examples of some drugs containing a thiophene ring are tiagabine (Gabitril), raloxifene (Evista), olanzapine (Zyprexa) or clopidogrel (Plavix) (Figure 1). These 
compounds are widely used in the treatment of several diseases, the first is an anticonvulsant, the second is an oral selective estrogen receptor modulator with estrogenic actions on bone (prevention of osteoporosis) [17], the third is an antipsychotic [18] and the latter is one of the most successful platelet aggregation inhibitors [19].

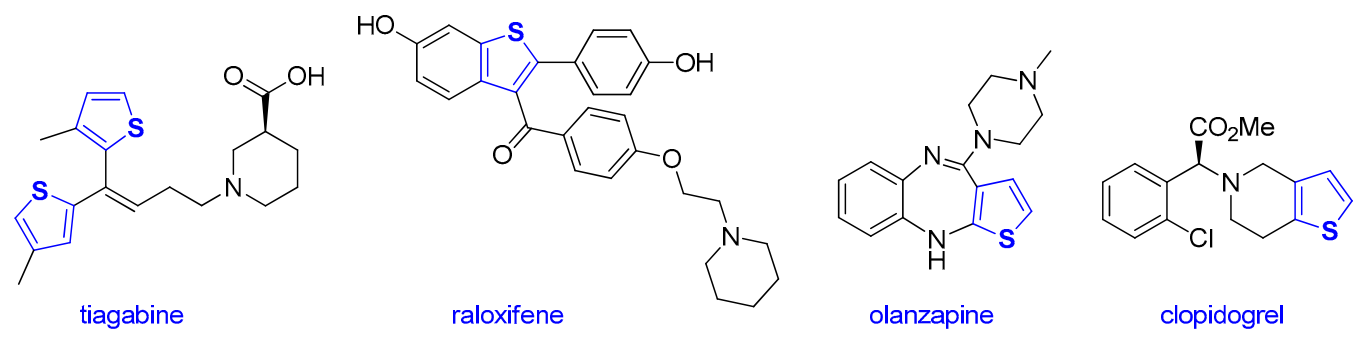

Figure 1. Drugs containing the thiophene ring.

Within our research line in gold and silver compounds as antitumoral agents [20-24], here we report on the synthesis of a thiophene-substituted phosphine ligand and the studies of coordination to gold or silver complexes. The cytotoxicity of these derivatives in several cancer cell lines has been carried out, showing excellent activities in all of them.

\section{Results and Discussion}

\subsection{Synthesis and Characterization}

The synthesis of the new ligand containing the thiophene moiety was achieved by reaction of thiophenecarbonylchloride with the aminophosphine $\mathrm{Ph}_{2} \mathrm{PCH}_{2} \mathrm{CH}_{2} \mathrm{NH}_{2}$ in a 1:1 ratio in the presence of triethylamine, which results in the formation of the ligand $\mathrm{C}_{4} \mathrm{H}_{3} \mathrm{SNHCOCH}_{2} \mathrm{CH}_{2} \mathrm{PPh}_{2}(\mathbf{L})$ in good yield (see Scheme 1). In the ${ }^{1} \mathrm{H}$ NMR spectrum of $\mathbf{L}$ the signals of the protons $\mathrm{H} 3$ and $\mathrm{H} 5$ of the thiophene group are overlapped with the resonances due to the phenyl protons. The resonance for the $\mathrm{H} 4$ of the thiophene appears at $7.02 \mathrm{ppm}$ as a triplet, and the NH proton of the amide group is observed at 6.25 as a broad doublet. The protons of the methylene groups appear at 3.61 and $2.42 \mathrm{ppm}$. The ${ }^{13} \mathrm{C}\left\{{ }^{1} \mathrm{H}\right\}$ APT presents the expected resonances for all functional groups, the carbon of the CO group appears at $161.76 \mathrm{ppm}$, the carbon atoms of the thiophene at 138.99, 129.98, 128.01 and $127.64 \mathrm{ppm}$ and the methylene carbons at 37.56 and $28.63 \mathrm{ppm}$. The ${ }^{31} \mathrm{P}\left\{{ }^{1} \mathrm{H}\right\}$ spectrum presents only one resonance for the free phosphorus atom at $-20.6 \mathrm{ppm}$.

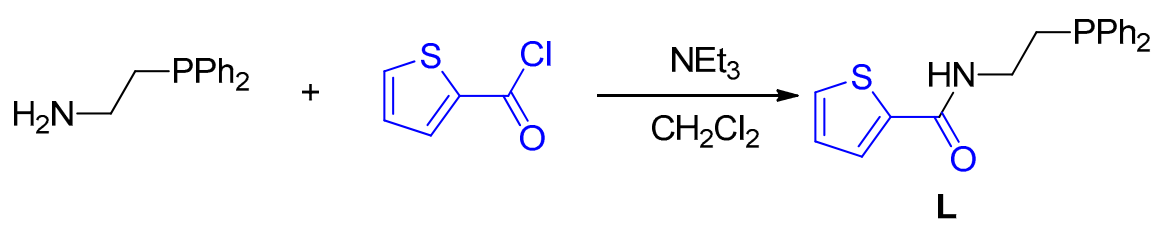

Scheme 1. Synthesis of the ligand $\mathbf{L}$.

The coordination behavior of $\mathbf{L}$ with several gold and silver complexes has been studied. In first place the reaction of the complex $\left[\mathrm{Au}(\mathrm{tht})_{2}\right] \mathrm{OTf}$ (tht $=$ tetrahydrothiophene; $\mathrm{OTf}=$ trifluoromethanesulphonate) with $\mathbf{L}$ in a 1:2 ratio in dichloromethane results in the formation of complex $\left[\mathrm{AuL}_{2}\right] \mathrm{OTf}(\mathbf{1})$ with good yields (see Scheme 2). The ${ }^{31} \mathrm{P}\left\{{ }^{1} \mathrm{H}\right\}$ NMR spectrum showed a signal at $37.0 \mathrm{ppm}$, which confirms a low field shift of $57 \mathrm{ppm}$ relative to the free ligand, due to the coordination of the metal fragment to the phosphorus atom of the ligand. All resonances of the ligand were observed in the proton NMR spectrum and, as expected, the methylene groups near the phosphine move slightly to a low field due to the coordination of the metal. The proton of the amide group - NH- undergoes a low field shift of $1.54 \mathrm{ppm}$, probably due to the formation of intermolecular hydrogen bonds with the carbonyl group of another molecule. 
The reaction of $\mathbf{L}$ with the gold(I) species [AuCl(tht)] or $\left[\mathrm{Au}\left(\mathrm{C}_{6} \mathrm{~F}_{5}\right)(\right.$ tht $\left.)\right]$ or the gold(III) derivative $\left[\mathrm{Au}\left(\mathrm{C}_{6} \mathrm{~F}_{5}\right)_{3}(\mathrm{tht})\right]$ in dichloromethane in a 1:1 molar ratio afforded the mononuclear linear gold(I) complexes $[\mathrm{AuX}(\mathrm{L})]\left(\mathrm{X}=\mathrm{Cl}(2), \mathrm{C}_{6} \mathrm{~F}_{5}(3)\right)$ or the square planar gold(III) compound $\left[\mathrm{Au}\left(\mathrm{C}_{6} \mathrm{~F}_{5}\right)_{3}(\mathrm{~L})\right]$ in good yields (see Scheme 2). The complexes have been characterized by IR, NMR spectroscopy and mass spectrometry. In the IR spectra the absorptions for the $v(\mathrm{Au}-\mathrm{Cl})$ in complex 2 and the vibrations due to the pentafluorophenyl rings bonded to gold(I) or gold(III) for compounds 3 or 4 were observed. In the ${ }^{31} \mathrm{P}\left\{{ }^{1} \mathrm{H}\right\}$ NMR spectra a downfield displacement for the phosphorus atoms is observed as a consequence of the coordination to the gold center, with resonances at $24 \mathrm{ppm}$ for the gold(I) species and at $11 \mathrm{ppm}$ for the gold(III) derivative. The ${ }^{19} \mathrm{~F}$ spectra for compounds 3 and 4 are also characteristic of the coordination of the ligand to the $\mathrm{AuC}_{6} \mathrm{~F}_{5}$ or the $\mathrm{Au}\left(\mathrm{C}_{6} \mathrm{~F}_{5}\right)_{3}$ fragments, with three or six resonances for the ortho, meta and para fluorine of the pentafluorophenyl groups, respectively.

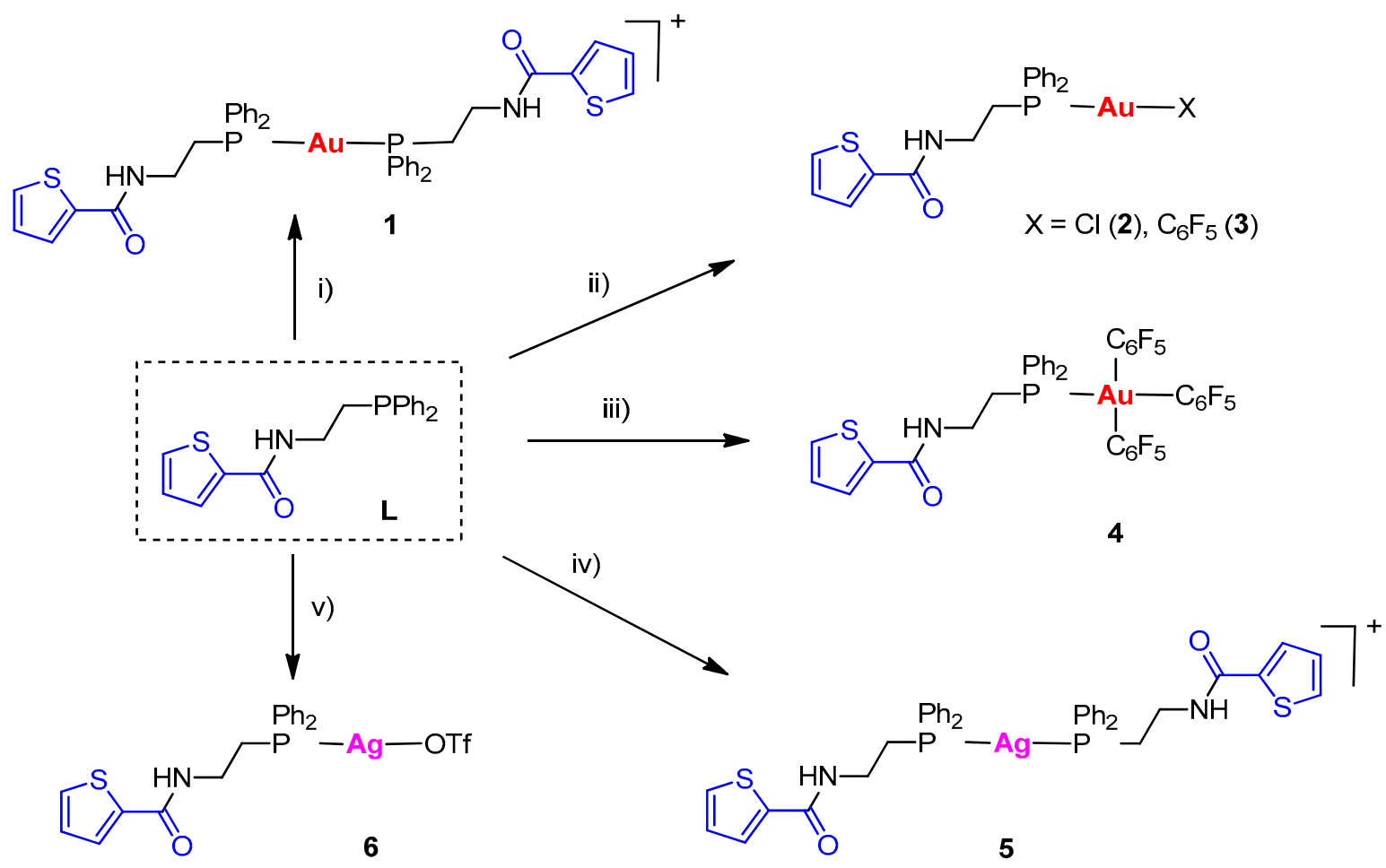

Scheme 2. Coordination studies of ligand L. Reaction conditions: $\mathrm{CH}_{2} \mathrm{Cl}_{2}$, r.t., (i) [Au(tht) $\left.{ }_{2}\right] \mathrm{OTf}$ : (ii) $[\mathrm{AuCl}($ tht $)]$ or $\left[\mathrm{Au}\left(\mathrm{C}_{6} \mathrm{~F}_{5}\right)\right.$ (tht)]; (iii) $\left[\mathrm{Au}\left(\mathrm{C}_{6} \mathrm{~F}_{5}\right)_{3}(\right.$ tht $\left.)\right]$; (iv) $1 / 2 \mathrm{Ag}(\mathrm{OTf})$; (v) $\mathrm{Ag}(\mathrm{OTf})$.

The reaction of the chloro-gold derivative 2 with different thiols derived from DNA-bases or related species, such as 2-thiocitosine, 2-thiolpyridine, 2-thiouracil, 2-thionicotinic acid, 2,3,4,6-tetra-6-acetyl-1-thiol- $\mu$-D-glucopyranosato or thiopurine were carried out in dichloromethane in the presence of potassium carbonate to afford the phosphine-thiolate gold derivatives 7-12 (see Scheme 3). 

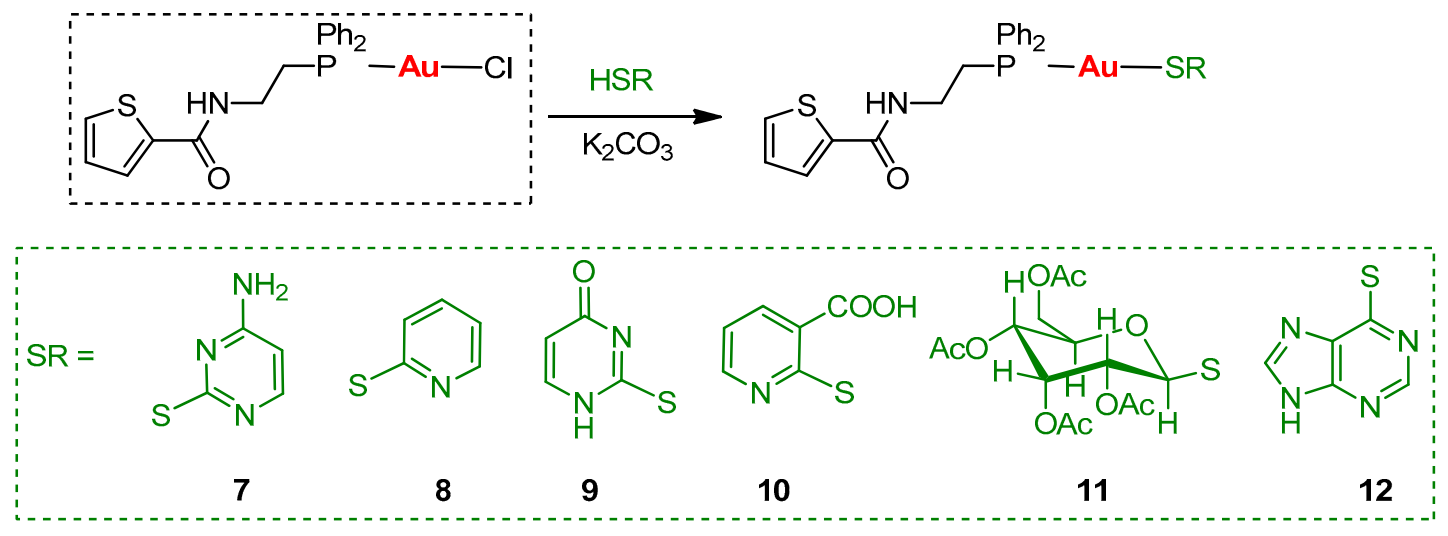

Scheme 3. Synthesis of the thiolate-gold(I) derivatives.

The NMR data for these complexes are in accordance with the substitution of the chlorine ligand for the corresponding thiolate. The resonances in the ${ }^{1} \mathrm{H}$ and ${ }^{13} \mathrm{C}$ NMR spectra corroborate the presence of both the amide-phosphine and the thiolate ligand. In the ${ }^{31} \mathrm{P}\left\{{ }^{1} \mathrm{H}\right\} \mathrm{NMR}$ the resonances for the phosphorus atom are displaced downfield.

\subsection{X-ray Diffraction Studies}

Molecular structures of complexes 3, 6 and 7 were confirmed by an X-ray crystallographic study. Complexes 3 and 6 crystallized in the monoclinic space group P2 $2_{1} / n$ with two or one molecules by an asymmetric unit, respectively. Compound 7 crystallized in the triclinic space group $P-1$ with two molecules by asymmetric unit. Figure 2 collects the molecular structures for the pentafluorophenyl and thiolate gold(I) derivatives.
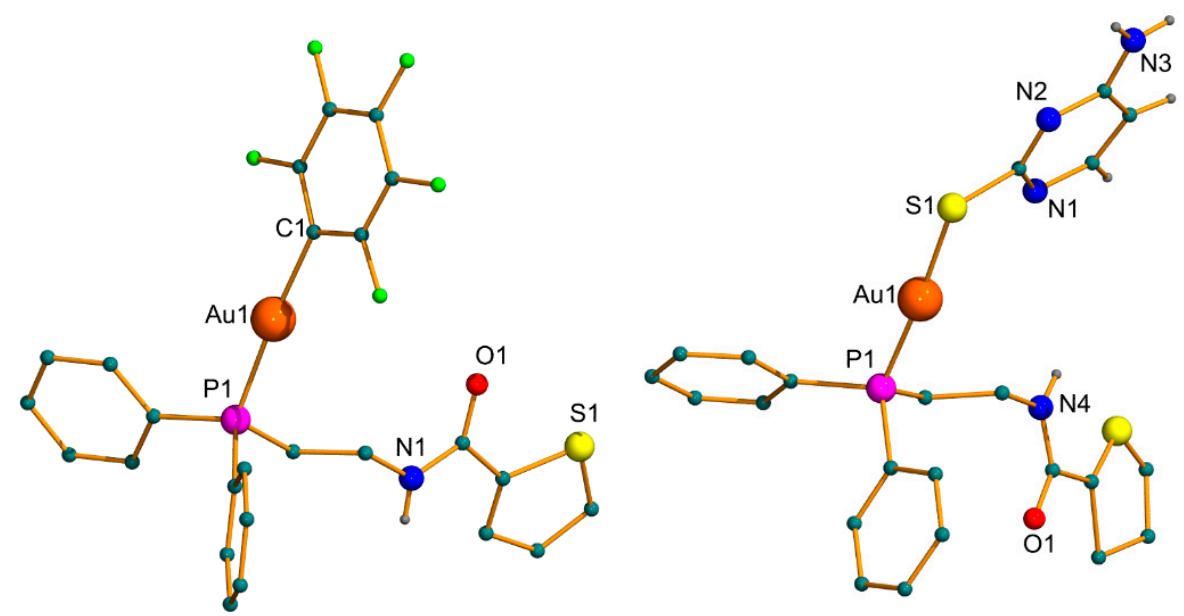

Figure 2. Molecular structure of the gold compounds 3 and 7, with the atom labelling scheme (some of the hydrogen atoms are omitted for clarity).

The gold(I) atoms in complexes 3 and 7 lie in an almost linear geometry, as expected for gold(I) derivatives, defined by the $\mathrm{P}$ atom and the $\mathrm{C}$ of the pentafluorophenyl (3) or the $\mathrm{S}$ atom of the thiolate ligand (7). The $\mathrm{P}-\mathrm{Au}-\mathrm{C}$ bond angles in 3 are $175.9(3)^{\circ}$ and $170.6(3)^{\circ}$, and the $\mathrm{P}-\mathrm{Au}-\mathrm{S}$ bond angles are $176.02(7)^{\circ}$ and $173.55(8)^{\circ}$ in 7 . The $\mathrm{Au}-\mathrm{P}, \mathrm{Au}-\mathrm{C}$, and $\mathrm{Au}-\mathrm{S}$ bond distances are unexceptional for both complexes and compared well with most of the distances found in related complexes with the same $\mathrm{C}_{6} \mathrm{~F}_{5}-\mathrm{Au}-\mathrm{P}$ or $\mathrm{S}-\mathrm{Au}-\mathrm{P}$ core $[25,26]$. The longer $\mathrm{Au}-\mathrm{P}$ bond distances in the pentafluorophenyl derivative 3 (2.276(3) $\AA, 2.273(3) \AA$ ) compared with those in complex 7 (2.256(2) $\AA, 2.256(2) \AA)$ and are in agreement with the higher trans influence of the pentafluorophenyl ligand compared with the thiolate ligand. 
In the crystal of 3 the molecules are associated into chains parallel to the crystallographic b-axis via short hydrogen bonds between the amide $\mathrm{NH}$ proton and the oxygen atom of the $\mathrm{CO}$ group of neighbouring molecules as a proton acceptor (Figure 3). The distances and angles of the D $\cdots$ A moieties

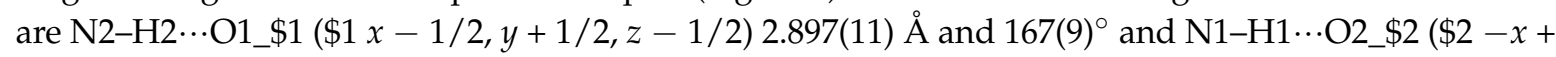
$1,-y+1,-z+1) 2.918(11) \AA$ and $148.1^{\circ}$.

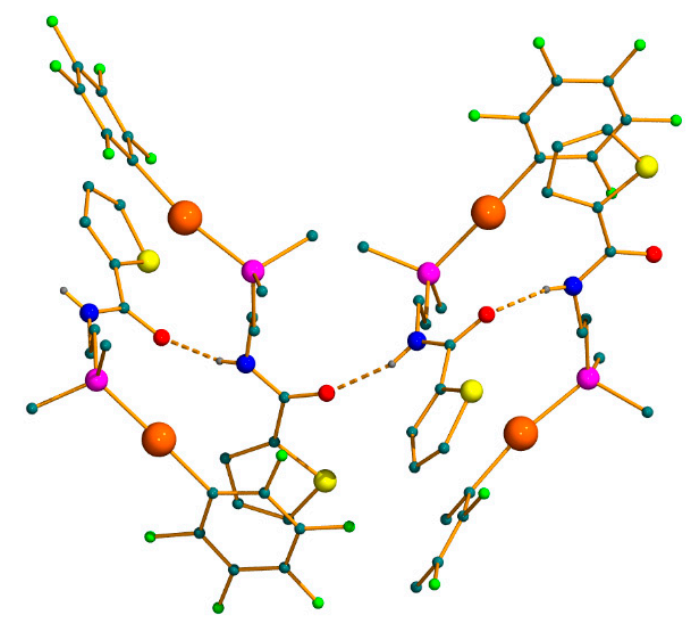

Figure 3. Association of molecules in 3 via hydrogen bonding.

In the crystal of 7 the molecules are organized into dimers though classical $\mathrm{H}$-bonds $(\mathrm{N}-\mathrm{H} \cdots \mathrm{N})$

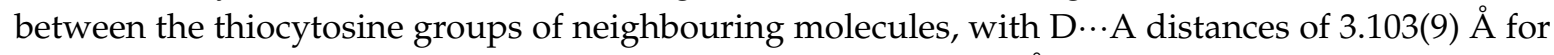
$\mathrm{N} 3-\mathrm{H} 3 \mathrm{~b} \cdots \mathrm{N} 5$ with an angle of $147.5^{\circ}$ and a distance of 3.059(9) $\AA$ for N3-H3a $\cdots \mathrm{N} 2 \_\$ 1(\$ 1-x+1$, $-y+2,-z+1)$ with an angle of $169.1 \mathrm{C}$. Moreover, dimers are organized in a 3D array through additional H-bond $(\mathrm{N}-\mathrm{H} \cdot \mathrm{N}), \mathrm{N} 7-\mathrm{H7a} \cdots \mathrm{N} 6 \_\$ 2(\$ 2-x+2,-y+1,-z-1)$ distance of 3.124(10) with an angle of $170.3^{\circ}$ (Figure 4).

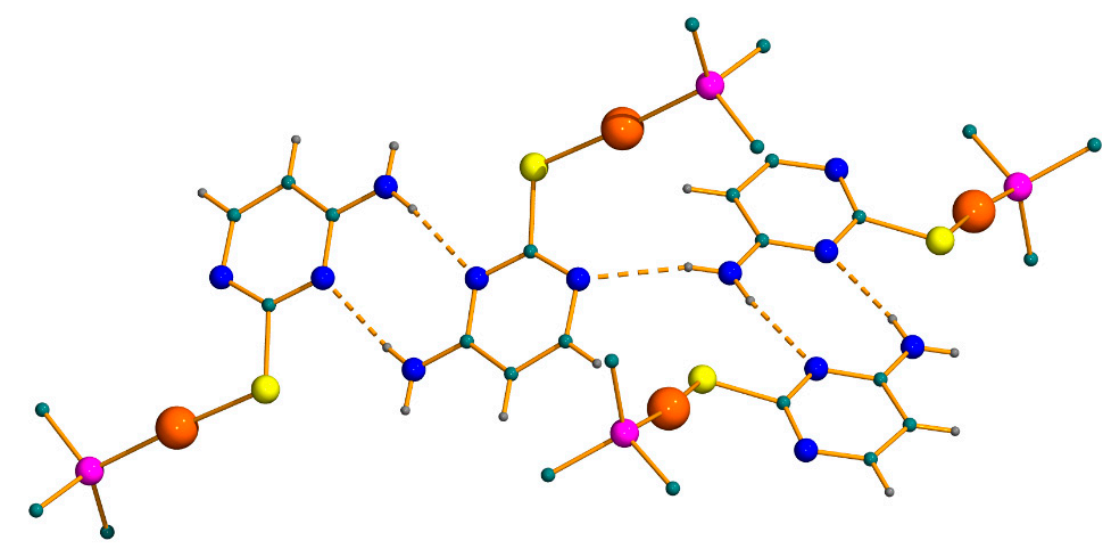

Figure 4. Association of molecules in complex 7 via hydrogen bonding. Phenyl rings are omitted for clarity, only ipso carbon is maintained.

Complex $\mathbf{6}$ can be seen as chains of silver atoms in which the thiophene-phosphine group is acting as a bidentate bridging ligand through the $\mathrm{P}$ atom and the $\mathrm{O}$ of the carboxamide group atom (Figure 5). In addition, each triflate anion is bonded to two silver atoms of different chains that lead to a 3D array. The silver atom is in a highly distorted tetrahedral geometry. The angles around the silver center range from $77.4(2)^{\circ}$ to $155.0(1)^{\circ}$. The bond lenghts are normal in tetra-coordinated silver compounds, with Ag-P distance of 2.380(2) $\AA$ and Ag-O carboxamide distance of 2.265(4) $\AA$, whereas the Ag-O triflate bonds (2.444(4) $\AA$ and 2.574(4) $\AA$ ) are longer than the carboxamide oxygen. However, these Ag-O distances are shorter than the usually found in silver-triflate complexes with weak bonds $[27,28]$. 


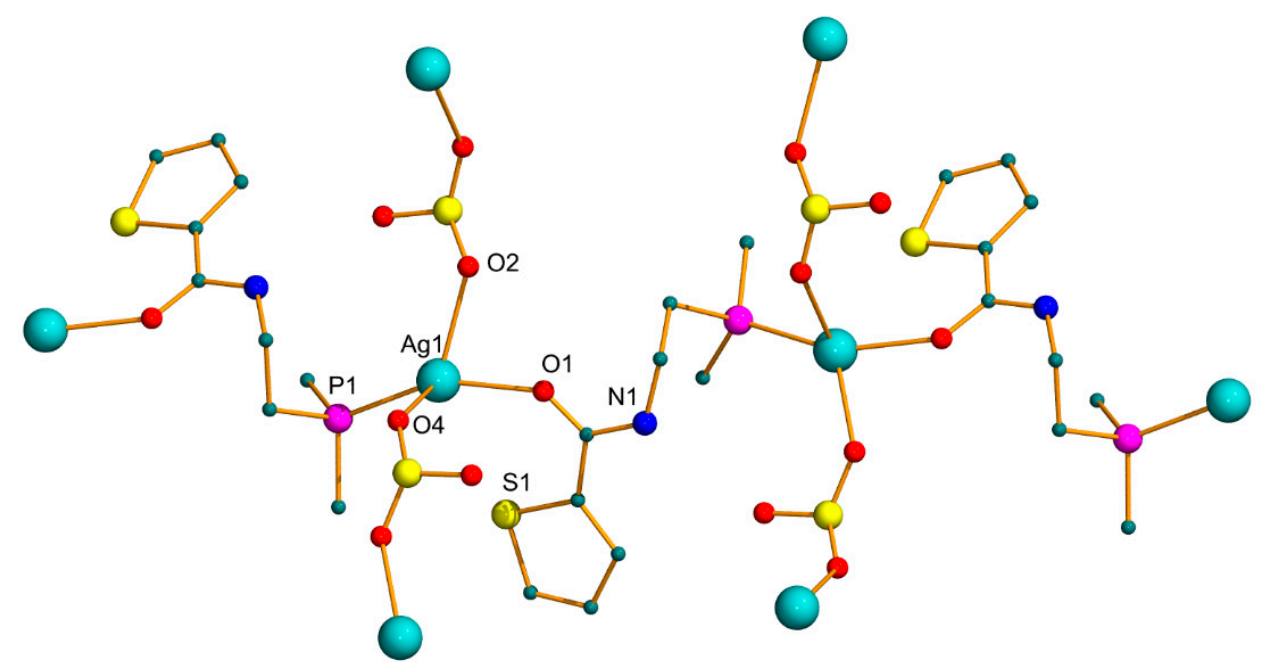

Figure 5. Structure of compound 6, with the atom labelling scheme, showing the tridimensional network (hydrogen atoms, phenyl rings and the $\mathrm{CF}_{3}$ units from the triflate are omitted for clarity).

\subsection{Biological Studies}

The cytotoxic activity of ligand $\mathbf{L}$ and the gold and silver complexes 1-12 were tested against four different tumor cell lines: A-549 (human lung carcinoma), Hep-G2 (human liver cancer), NIH-3T3 (mouse embryonic fibroblast) or PC12 (pheochromocytoma of the rat adrenal medulla) and comparison with that of cisplatin has been performed [29-31].

Compounds L and 1-10 are not water-soluble, but they are soluble in DMSO and in the DMSO/water mixtures used in to perform the tests, containing a small amount of DMSO, concentrations up to $100 \mu \mathrm{M}$. No precipitation of the compounds, or metallic gold or silver was observed while performing the tests. Their DMSO- $d_{6}$ solutions are stable at room temperature, according to the ${ }^{1} \mathrm{H}$ NMR spectra in which the same resonances were present for more than two weeks. Cells were exposed to various concentrations of each compound for a total of $48 \mathrm{~h}$. The $\mathrm{IC}_{50}$ values were calculated using the colorimetric MTT viability assay, (MTT = 3-(4,5-dimethyl-thiazol-2-yl)-2,5-diphenyltetrazolium bromide). The final concentration of DMSO was $<0.1 \%$. $\mathrm{IC}_{50}$ values are necessary concentrations of a drug to inhibit tumor cell proliferation by $50 \%$, compared to the control cells treated with DMSO alone. The $\mathrm{IC}_{50}$ values for $\mathbf{L}$ and complexes 1-12 are collected in Table 1.

Table 1. $\mathrm{IC}_{50}$ of $\mathbf{L}$ and complexes $\mathbf{1}-\mathbf{1 2}$ at $48 \mathrm{~h}(\mu \mathrm{M})$.

\begin{tabular}{ccccc}
\hline \multicolumn{5}{c}{ IC $_{\mathbf{5 0}}(\boldsymbol{\mu M})$} \\
\hline Complex & A-549 & Hep-G2 & NIH-3T3 & PC-12 \\
\hline $\mathbf{L}$ & $>100$ & $>100$ & $>100$ & $>100$ \\
$\mathbf{1}$ & $48.9 \pm 2.1$ & $17.1 \pm 1.1$ & $1.4 \pm 0.09$ & $0.5 \pm 0.1$ \\
$\mathbf{2}$ & $>100$ & $16.9 \pm 1.2$ & $2.8 \pm 0.9$ & $1.6 \pm 0.8$ \\
$\mathbf{3}$ & $10.6 \pm 1.4$ & $56 \pm 3.5$ & $39.37 \pm 2.2$ & $1.6 \pm 0.7$ \\
$\mathbf{4}$ & $>100$ & $>100$ & $>100$ & $>100$ \\
$\mathbf{5}$ & $20.8 \pm 2.1$ & $10.0 \pm 1.1$ & $4.0 \pm 0.8$ & $1.1 \pm 0.6$ \\
$\mathbf{6}$ & $12.5 \pm 1.2$ & $78.9 \pm 2.4$ & $20.8 \pm 1.8$ & $6.9 \pm 1.0$ \\
$\mathbf{7}$ & $45.1 \pm 2.7$ & $5.9 \pm 1.7$ & $3.0 \pm 1.2$ & $1.0 \pm 0.5$ \\
$\mathbf{8}$ & $24.5 \pm 1.8$ & $6.7 \pm 2.3$ & $2.1 \pm 0.4$ & $0.5 \pm 0.2$ \\
$\mathbf{9}$ & $>100$ & $14.1 \pm 2.5$ & $6.1 \pm 1.9$ & $1.3 \pm 0.4$ \\
$\mathbf{1 0}$ & $>100$ & $15.8 \pm 2.4$ & $6.3 \pm 1.7$ & $2.7 \pm 1.0$ \\
$\mathbf{1 1}$ & $9.9 \pm 1.4$ & $5.9 \pm 1.1$ & $2.9 \pm 0.9$ & - \\
$\mathbf{1 2}$ & $65.7 \pm 3.4$ & $>100$ & $13.7 \pm 2.4$ & - \\
Cisplatin & 64 & $25 \pm 3.1$ & $145 \pm 13$ & - \\
\hline
\end{tabular}


The $\mathrm{IC}_{50}$ values listed in Table 1 showed that the tested thiophene amidophosphine ligand (L) did not show significant antiproliferative activity and neither the gold(III) complex bearing pentafluorophenyl groups (4). However, the rest of the compounds were quite effective as cytotoxic agents against in vitro growth of the tested cancer cell lines. They showed certain selectivity in their cytotoxic action, being the A549 and the Hep-G2 cell lines the more resistant and the PC-12 the most sensitive in all the tested compounds.

The bis(amidophosphine) gold (1) or silver (5) complexes exhibited excellent activities with low $\mathrm{IC}_{50}$ values in all the cell lines, especially the silver species $\mathbf{5}$ showed $\mathrm{IC}_{50}$ values ranging from 1.1 to 20.8 cells. The chloro-gold derivative 2 did not show significant activity in A549 cancer cells, whereas presented excellent results in the other cell lines. Surprisingly, the gold(I) species with a pentafluorophenyl moiety 3 showed very good activity in A549 cancer cells, in contrast to the lower activity observed in our group for other gold complexes with pentafluorophenyl ligands. The best results in the thiolate gold derivatives were achieved with the 2,3,4,6-tetra-6-acetyl-1-thiol- $\beta$-D-glucopyranosato ligand, complex 11, for which excellent activities were obtained in all the cancer cell lines.

With these results is possible to get some interesting structure activity relationships. The tested thiophene amidophosphine derivatives showed excellent activities in PC-12 and NIH-3T3 cell lines. Interestingly, the gold complexes exhibited slightly better activity than the silver compounds with the exception of the A549 cell line for which the silver species are more active. The best results were obtained for the thiolate-gold derivatives, specifically with the 2,3,4,6-tetra-6-acetyl-1-thiol- $\beta$-D-glucopyranosato ligand, although in general the other thiolate gold complexes presented dissimilar $\mathrm{IC}_{50}$ values depending on the cell line. Excellent values were also achieved with the bis(phosphine) gold and silver complexes, probably because of their cationic character. Practically in most of the cases the antiproliferative activity was superior to that presented by cisplatin.

\section{Experimental Section}

\subsection{Instrumentation}

Mass spectra were recorded on a BRUKER ESQUIRE 3000 PLUS (Bruker, Bremen, Germany), with the electrospray (ESI) technique and on a BRUKER MICROFLEX (MALDI-TOF) (Bruker, Bremen, Germany), using Dithranol or a T-2-(3-(4-tbutyl-phenyl)-2-methyl-2-propenylidene)malononitrile as a matrix. NMR spectra were recorded with a Bruker ARX 400 spectrometer (Bruker, Bremen, Germany) $\left({ }^{1} \mathrm{H}, 400 \mathrm{MHz}\right.$ and $\left.{ }^{19} \mathrm{~F}, 376.5 \mathrm{MHz}\right)$. Chemical shifts are reported in ppm relative to the residual solvent peak $\left[{ }^{1} \mathrm{H}\left(\mathrm{CD}_{3}\right)_{2} \mathrm{CO}: 2.05\right]$ and $\mathrm{CFCl}_{3}$, respectively.

\subsection{Starting Materials}

[AuCl(tht)], [Au( $\left.\left.\mathrm{C}_{6} \mathrm{~F}_{5}\right)(\mathrm{tht})\right]$ [32], [Au(tht $\left.)_{2}\right] \mathrm{OTf}[33,34]$ and $\left[\mathrm{Au}\left(\mathrm{C}_{6} \mathrm{~F}_{5}\right)_{3}(\mathrm{tht})\right]$ [32], were prepared according to literature procedures. Other starting materials and solvents are commercially available.

\subsection{General Procedure for the Synthesis of Ligand $\mathbf{L}$ and Complexes 1-6}

Synthesis of 2-(diphenylphosphino)ethylamine-2-carbonylthiophene (L): To a solution of 2-(diphenylphosphino)ethylamine $(46 \mu \mathrm{L}, 0.2 \mathrm{mmol})$ in $\mathrm{CH}_{2} \mathrm{Cl}_{2}(20 \mathrm{~mL})$ was added triethylamine $(60 \mu \mathrm{L}, 0.43 \mathrm{mmol})$. After stirring the solution for $10 \mathrm{~min}$ at room temperature, it was poured onto an ice bath and a solution of 2-chlorocarbonylthiophene in $\mathrm{CH}_{2} \mathrm{Cl}_{2}(20 \mathrm{~mL})$ was added dropwise and stirred overnight. An aqueous solution of $\mathrm{NaHCO}_{3}(30 \mathrm{~mL})$ was added and the two phases were separated. The organic phase was dried with anhydrous $\mathrm{Na}_{2} \mathrm{SO}_{4}$. The solvent was evaporated to ca. $5 \mathrm{~mL}$ and hexane $(20 \mathrm{~mL})$ was added to obtain a white solid. $80 \%$ yield. ${ }^{1} \mathrm{H}$ NMR $\left(\mathrm{CDCl}_{3}\right) \delta(\mathrm{ppm})$ : 7.45 (m, 6H, Ph, H3, H5), 7.34 (m, 6H, Ph), 7.02 (dd, J = 4.8 Hz, $3.6 \mathrm{~Hz}, 1 \mathrm{H}, \mathrm{H} 4), 6.25$ (m, br, 1H, NH), $3.61\left(\mathrm{~m}, 2 \mathrm{H},-\mathrm{CH}_{2} \mathrm{~N}-\right), 2.42\left(\mathrm{t}, J=7.2 \mathrm{~Hz}, 2 \mathrm{H},-\mathrm{CH}_{2} \mathrm{P}-\right) .{ }^{13} \mathrm{C}\left\{{ }^{1} \mathrm{H}\right\} \mathrm{NMR}\left(\mathrm{CDCl}_{3}\right) \delta(\mathrm{ppm}): 161.76(\mathrm{C}=\mathrm{O})$, 
$138.99(\mathrm{C} 2), 137.70\left(\mathrm{~d},{ }^{1} \mathrm{~J}_{\mathrm{PC}}=11.7 \mathrm{~Hz}, i p s o-\mathrm{C}_{6} \mathrm{H}_{5}\right), 132.87\left(\mathrm{~d},{ }^{2} J_{\mathrm{PC}}=18.8 \mathrm{~Hz}, o-\mathrm{C}_{6} \mathrm{H}_{5}\right), 129.98(\mathrm{C} 3), 129.04$ $\left(p-\mathrm{C}_{6} \mathrm{H}_{5}\right), 128.79\left(\mathrm{~d},{ }^{3} J_{\mathrm{PC}}=6.9 \mathrm{~Hz}, m-\mathrm{C}_{6} \mathrm{H}_{5}\right), 128.01(\mathrm{C} 5), 127.64(\mathrm{C} 4), 37.56\left(\mathrm{~d},{ }^{2} J_{\mathrm{C}-\mathrm{P}}=19.9 \mathrm{~Hz},-\mathrm{CH}_{2} \mathrm{~N}-\right)$, $28.63\left(\mathrm{~d},{ }^{1} J_{\mathrm{C}-\mathrm{P}}=13.3 \mathrm{~Hz},-\mathrm{CH}_{2} \mathrm{P}-\right) .{ }^{31} \mathrm{P}\left\{{ }^{1} \mathrm{H}\right\} \mathrm{NMR}\left(\mathrm{CDCl}_{3}\right) \delta(\mathrm{ppm}):-20.64$.

Synthesis [AuL $\mathrm{A}_{2}$ ]OTf (1): To a solution of $\mathbf{L}(0.1018 \mathrm{~g}, 0.30 \mathrm{mmol})$ in $\mathrm{CH}_{2} \mathrm{Cl}_{2}(20 \mathrm{~mL})$, [Au(tht $)_{2}$ ]OTf $(0.0783 \mathrm{~g}, 0.15 \mathrm{mmol})$ was added and the solution was stirred for $1 \mathrm{~h}$. Evaporation of the solvent to ca. $5 \mathrm{~mL}$ and addition of hexane $(15 \mathrm{~mL})$ gave a white solid of $1.73 \%$ yield. ${ }^{1} \mathrm{H}$ NMR $\left(\mathrm{CDCl}_{3}\right) \delta(\mathrm{ppm})$ : $7.79(\mathrm{~m}, 2 \mathrm{H}, \mathrm{NH}), 7.53(\mathrm{~m}, 10 \mathrm{H}, \mathrm{Ph}, \mathrm{H} 3), 7.39$ (m, 14H, Ph, H5), $6.92(\mathrm{dd}, J=4.9,3.9 \mathrm{~Hz}, 2 \mathrm{H}, \mathrm{H} 4), 3.70$ $\left(\mathrm{m}, 4 \mathrm{H},-\mathrm{CH}_{2} \mathrm{~N}-\right), 2.82\left(\mathrm{t}, J=6.4 \mathrm{~Hz}, 4 \mathrm{H},-\mathrm{CH}_{2} \mathrm{P}-\right) .{ }^{13} \mathrm{C}\left\{{ }^{1} \mathrm{H}\right\} \mathrm{NMR}\left(\mathrm{CDCl}_{3}\right) \delta(\mathrm{ppm}): 162.96(\mathrm{C}=\mathrm{O})$, $138.84(\mathrm{C} 2), 133.08\left(o-\mathrm{C}_{5} \mathrm{H}_{4}\right), 131.28\left(p-\mathrm{C}_{5} \mathrm{H}_{4}\right), 130.37(\mathrm{C} 3), 129.47\left(m-\mathrm{C}_{5} \mathrm{H}_{4}\right), 128.66(\mathrm{C} 5), 127.96$ (C4), $36.83\left(-\mathrm{CH}_{2} \mathrm{~N}-\right), 27.70\left(-\mathrm{CH}_{2} \mathrm{P}-\right) .{ }^{31} \mathrm{P}\left\{{ }^{1} \mathrm{H}\right\} \mathrm{NMR}\left(\mathrm{CDCl}_{3}\right) \delta(\mathrm{ppm}): 36.99 .{ }^{19} \mathrm{~F} \mathrm{NMR}\left(\mathrm{CDCl}_{3}\right) \delta(\mathrm{ppm})$ :

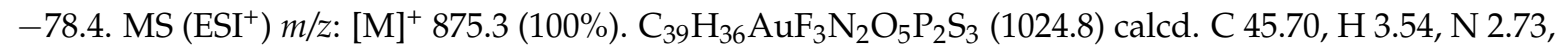
S 9.37; found C 45.48, H 3.35, N 2.73, S 8.97.

Synthesis of [AuClL] (2): To a solution of $\mathbf{L}(0.15 \mathrm{mmol})$ in $\mathrm{CH}_{2} \mathrm{Cl}_{2}(20 \mathrm{~mL})$, [AuCl(tht)] (0.15 mmol) was added and the mixture was stirred for $1 \mathrm{~h}$. Then, the solution was evaporated to ca. $5 \mathrm{~mL}$ and addition of hexane $(15 \mathrm{~mL})$ afforded a white solid of $2.94 \%$ yield. ${ }^{1} \mathrm{H}$ NMR $\left(\mathrm{CDCl}_{3}\right) \delta(\mathrm{ppm}): 7.69(\mathrm{~m}$, $4 \mathrm{H}, \mathrm{Ph}), 7.45$ (m, 8H, Ph, H3, H5), 7.03 (dd, $J=4.7,4.0 \mathrm{~Hz}, 1 \mathrm{H}, \mathrm{H} 4), 6.69(\mathrm{~m}, 1 \mathrm{H}, \mathrm{NH}), 3.74(\mathrm{~m}, 2 \mathrm{H}$, $\left.-\mathrm{CH}_{2} \mathrm{~N}-\right), 2.91\left(\mathrm{dt}, J=10.9 \mathrm{~Hz}, 7.1 \mathrm{~Hz}, 2 \mathrm{H},-\mathrm{CH}_{2} \mathrm{P}-\right) .{ }^{13} \mathrm{C}\left\{{ }^{1} \mathrm{H}\right\} \mathrm{NMR}\left(\mathrm{CDCl}_{3}\right) \delta(\mathrm{ppm}): 162.44(\mathrm{C}=\mathrm{O})$, $138.22(\mathrm{C} 2), 133.30\left(\mathrm{~d},{ }^{2} J_{\mathrm{PC}}=13.3 \mathrm{~Hz}, o-\mathrm{C}_{6} \mathrm{H}_{5}\right), 132.28\left(p-\mathrm{C}_{6} \mathrm{H}_{5}\right), 130.62(\mathrm{C} 3), 129.55\left(\mathrm{~d},{ }^{3} J_{\mathrm{PC}}=11.8 \mathrm{~Hz}\right.$, $\left.m-\mathrm{C}_{6} \mathrm{H}_{5}\right), 128.84\left(\mathrm{~d},{ }^{1} J_{\mathrm{PC}}=42.2 \mathrm{~Hz}\right.$, ipso- $\left.\mathrm{C}_{6} \mathrm{H}_{5}\right), 128.44(\mathrm{C} 5), 127.90(\mathrm{C} 4), 36.98\left(\mathrm{~d},{ }^{2} J_{\mathrm{C}-P}=5.6 \mathrm{~Hz}\right.$, $\left.-\mathrm{CH}_{2} \mathrm{~N}-\right), 28.35\left(\mathrm{~d},{ }^{1} J_{C-P}=39.1 \mathrm{~Hz},-\mathrm{CH}_{2} \mathrm{P}-\right) .{ }^{31} \mathrm{P}\left\{{ }^{1} \mathrm{H}\right\} \mathrm{NMR}\left(\mathrm{CDCl}_{3}\right) \delta(\mathrm{ppm}): 24.55 . \mathrm{C}_{19} \mathrm{H}_{18} \mathrm{AuClNOPS}$ (571.8) calcd. C 39.91, H 3.17, N 2.45, S 5.61; found C 39.61, H 3.08, N 2.60, S 5.39.

Synthesis of [Au( $\left.\mathbf{C}_{6} \mathrm{~F}_{5}\right) \mathbf{L}$ ] (3): To a solution of $\mathbf{L}(0.15 \mathrm{mmol})$ in $\mathrm{CH}_{2} \mathrm{Cl}_{2}(20 \mathrm{~mL})$, [ $\left.\mathrm{Au}\left(\mathrm{C}_{6} \mathrm{~F}_{5}\right)(\mathrm{tht})\right]$ $(0.15 \mathrm{mmol})$ was added and the solution was stirred for $1 \mathrm{~h}$. Evaporation of the solvent to ca. 5 $\mathrm{mL}$ and addition of hexane $(15 \mathrm{~mL})$ gave a white solid of $3.75 \%$ yield. ${ }^{1} \mathrm{H}$ NMR $\left(\mathrm{CDCl}_{3}\right) \delta(\mathrm{ppm})$ : $7.66(\mathrm{~m}, 4 \mathrm{H}, \mathrm{Ph}), 7.51(\mathrm{~d}, J=3.3 \mathrm{~Hz}, 1 \mathrm{H}, \mathrm{H} 3), 7.40(\mathrm{~m}, 7 \mathrm{H}, \mathrm{Ph}, \mathrm{H} 5), 7.07(\mathrm{t}, J=5.5 \mathrm{~Hz}, 1 \mathrm{H}, \mathrm{NH}), 7.0$ (m, 1H, H4), $\left.3.70\left(\mathrm{~m}, 1 \mathrm{H},-\mathrm{CH}_{2} \mathrm{~N}-\right), 2.89\left(\mathrm{~m}, 1 \mathrm{H},-\mathrm{CH}_{2} \mathrm{P}-\right) .{ }^{13} \mathrm{C}_{\{}{ }^{1} \mathrm{H}\right\} \mathrm{NMR}\left(\mathrm{CDCl}_{3}\right) \delta(\mathrm{ppm}): 162.36$ $(\mathrm{C}=\mathrm{O}), 137.15(\mathrm{C} 2), 133.48\left(\mathrm{~d},{ }^{2} J_{\mathrm{PC}}=13.4 \mathrm{~Hz}, o-\mathrm{C}_{6} \mathrm{H}_{5}\right), 132.01\left(\mathrm{~d},{ }^{4} J_{\mathrm{PC}}=2.1 \mathrm{~Hz}, p-\mathrm{C}_{6} \mathrm{H}_{5}\right), 130.55(\mathrm{C} 3)$, $130.06\left(\mathrm{~d},{ }^{1} J_{\mathrm{PC}}=53.8 \mathrm{~Hz}, i p s o-\mathrm{C}_{6} \mathrm{H}_{5}\right), 129.61\left(\mathrm{~d},{ }^{3} J_{\mathrm{PC}}=11.2 \mathrm{~Hz}, m-\mathrm{C}_{6} \mathrm{H}_{5}\right), 128.36(\mathrm{C} 5), 127.67(\mathrm{C} 4), 36.88$ $\left(\mathrm{d},{ }^{2} J_{\mathrm{C}-P}=6.2 \mathrm{~Hz},-\mathrm{CH}_{2} \mathrm{~N}-\right), 28.57\left(\mathrm{~d},{ }^{1} J_{\mathrm{C}-P}=33.3 \mathrm{~Hz},-\mathrm{CH}_{2} \mathrm{P}-\right) .{ }^{31} \mathrm{P}\left\{{ }^{1} \mathrm{H}\right\}-\mathrm{NMR}\left(\mathrm{CDCl}_{3}\right) \delta(\mathrm{ppm}): 24.24$. ${ }^{19} \mathrm{~F} \mathrm{NMR}\left(\mathrm{CDCl}_{3}\right) \delta(\mathrm{ppm}):-116.13\left(\mathrm{~m}, 2 \mathrm{~F}, o-\mathrm{C}_{6} \mathrm{~F}_{5}\right),-157.81\left(\mathrm{t}, J_{\mathrm{F}-\mathrm{F}}=19.96 \mathrm{~Hz}, 1 \mathrm{~F}, p-\mathrm{C}_{6} \mathrm{~F}_{5}\right),-161.97$ (m, $\left.2 \mathrm{~F}, m-\mathrm{C}_{6} \mathrm{~F}_{5}\right)$. $\mathrm{C}_{25} \mathrm{H}_{18} \mathrm{AuF}_{5} \mathrm{NOPS}$ (703.4) calcd. C 42.68, H 2.58, N 1.99, S 4.56; found C 42.65, H 2.84, $\mathrm{N} 2.01, \mathrm{~S} 4.73$.

Synthesis of [ $\left.\mathrm{Au}\left(\mathrm{C}_{6} \mathrm{~F}_{5}\right)_{3} \mathbf{L}\right]$ (4): To a solution of $\mathbf{L}(0.15 \mathrm{mmol})$ in $\mathrm{CH}_{2} \mathrm{Cl}_{2}(20 \mathrm{~mL})$, [ $\left.\mathrm{Au}\left(\mathrm{C}_{6} \mathrm{~F}_{5}\right)_{3}(\mathrm{tht})\right]$ $(0.15 \mathrm{mmol})$ was added and the mixture stirred for $1 \mathrm{~h}$. Then the solution was evaporated to ca. $5 \mathrm{~mL}$ and added hexane $(15 \mathrm{~mL})$ to obtain a white solid of $4.72 \%$ yield. ${ }^{1} \mathrm{H} \mathrm{NMR}\left(\mathrm{CDCl}_{3}\right) \delta(\mathrm{ppm}): 7.53$ (m, 11H, Ph, H3), $7.41(\mathrm{dd}, J=3.7,1.0 \mathrm{~Hz}, 1 \mathrm{H}, \mathrm{H} 5), 7.08(\mathrm{dd}, J=4.9,3.8 \mathrm{~Hz}, 1 \mathrm{H}, \mathrm{H} 4), 6.14(\mathrm{t}, J=5.9 \mathrm{~Hz}$, $\left.1 \mathrm{H}, \mathrm{NH}), 3.50\left(\mathrm{~m}, 2 \mathrm{H},-\mathrm{CH}_{2} \mathrm{~N}-\right), 2.90\left(\mathrm{~m}, 2 \mathrm{H},-\mathrm{CH}_{2} \mathrm{P}-\right) .{ }^{13} \mathrm{C}_{\{}{ }^{1} \mathrm{H}\right\} \mathrm{NMR}\left(\mathrm{CDCl}_{3}\right) \delta(\mathrm{ppm}): 162.35(\mathrm{C}=\mathrm{O})$, $137.62(\mathrm{C} 2), 133.11\left(\mathrm{~d},{ }^{4} J_{\mathrm{PC}}=2.7 \mathrm{~Hz}, p-\mathrm{C}_{6} \mathrm{H}_{5}\right), 132.76\left(\mathrm{~d},{ }^{2} J_{\mathrm{PC}}=10.4 \mathrm{~Hz}, o-\mathrm{C}_{6} \mathrm{H}_{5}\right), 130.94(\mathrm{C} 3), 129.53(\mathrm{~d}$, $\left.{ }^{3} J_{\mathrm{PC}}=11.6 \mathrm{~Hz}, m-\mathrm{C}_{6} \mathrm{H}_{5}\right), 128.77(\mathrm{C} 5), 128.01(\mathrm{C} 4), 123.18\left(\mathrm{~d},{ }^{1} J_{\mathrm{PC}}=57.7 \mathrm{~Hz}, i p s o-\mathrm{C}_{6} \mathrm{H}_{5}\right), 35.93\left(-\mathrm{CH}_{2} \mathrm{~N}-\right)$, $25.59\left(\mathrm{~d},{ }^{1} J_{\mathrm{C}-P}=29.6 \mathrm{~Hz},-\mathrm{CH}_{2} \mathrm{P}-\right) .{ }^{31} \mathrm{P}\left\{{ }^{1} \mathrm{H}\right\} \mathrm{NMR}\left(\mathrm{CDCl}_{3}\right) \delta(\mathrm{ppm}): 11.26\left(\mathrm{q}, J_{P-F}=11.10 \mathrm{~Hz}\right) .{ }^{19} \mathrm{~F} \mathrm{NMR}$ $\left(\mathrm{CDCl}_{3}\right) \delta(\mathrm{ppm}):-120.34\left(\mathrm{~m}, 4 \mathrm{~F}, o-\mathrm{C}_{6} \mathrm{~F}_{5}\right),-121.51\left(\mathrm{~m}, 2 \mathrm{~F}, o-\mathrm{C}_{6} \mathrm{~F}_{5}\right),-155.95\left(\mathrm{t}, J_{\mathrm{F}-\mathrm{F}}=19.92 \mathrm{~Hz}, 2 \mathrm{~F}\right.$, $\left.p-\mathrm{C}_{6} \mathrm{~F}_{5}\right),-156.80\left(\mathrm{t}, J_{\mathrm{F}-\mathrm{F}}=19.85 \mathrm{~Hz}, 1 \mathrm{~F}, p-\mathrm{C}_{6} \mathrm{~F}_{5}\right),-159.94\left(\mathrm{~m}, 4 \mathrm{~F}, m-\mathrm{C}_{6} \mathrm{~F}_{5}\right),-160.79\left(\mathrm{~m}, 2 \mathrm{~F}, m-\mathrm{C}_{6} \mathrm{~F}_{5}\right)$. MS $\left(\mathrm{ESI}^{+}\right) \mathrm{m} / z:\left[\mathrm{M}-\mathrm{C}_{6} \mathrm{~F}_{5}\right]^{+} 870.1$ (25.8\%). $\mathrm{C}_{37} \mathrm{H}_{18} \mathrm{AuF}_{15} \mathrm{NOPS}$ (1037.5) calcd. C 42.83, H 1.75, N 1.35, S 3.09; found C 43.01, H 1.79, N 1.38, S 3.16.

Synthesis of $\left[\mathbf{A g}(\mathbf{L})_{2}\right] \mathrm{OTf}$ (5): To a solution of $\mathbf{L}(0.30 \mathrm{mmol})$ in $\mathrm{CH}_{2} \mathrm{Cl}_{2}(20 \mathrm{~mL}), \mathrm{Ag}(\mathrm{OTf})(0.15 \mathrm{mmol})$ was added and the mixture stirred for $1 \mathrm{~h}$. The solution was evaporated to ca. $5 \mathrm{~mL}$ and addition of hexane $(15 \mathrm{~mL})$ afforded a white solid of $5.77 \%$ yield. ${ }^{1} \mathrm{H} \mathrm{NMR}\left(\mathrm{CDCl}_{3}\right) \delta(\mathrm{ppm}): 8.35(\mathrm{t}, J=5.5 \mathrm{~Hz}, 2 \mathrm{H}$, $\mathrm{NH}), 7.67(\mathrm{~m}, 8 \mathrm{H}, \mathrm{Ph}), 7.48(\mathrm{~m}, 14 \mathrm{H}, \mathrm{Ph}, \mathrm{H} 3), 7.36(\mathrm{~d}, J=4.9 \mathrm{~Hz}, 2 \mathrm{H}, \mathrm{H} 5), 6.96(\mathrm{dd}, J=4.8,3.9 \mathrm{~Hz}, 2 \mathrm{H}$, 
$\mathrm{H} 4), 3.82\left(\mathrm{~m}, 4 \mathrm{H},-\mathrm{CH}_{2} \mathrm{~N}-\right), 3.12\left(\mathrm{~m}, \mathrm{br}, 4 \mathrm{H},-\mathrm{CH}_{2} \mathrm{P}-\right) .{ }^{13} \mathrm{C}\left\{{ }^{1} \mathrm{H}\right\} \mathrm{NMR}\left(\mathrm{CDCl}_{3}\right) \delta(\mathrm{ppm}): 163.05(\mathrm{C}=\mathrm{O})$, $139.04(\mathrm{C} 2), 133.37\left(\mathrm{~d},{ }^{2} J_{\mathrm{PC}}=6.9 \mathrm{~Hz}, o-\mathrm{C}_{6} \mathrm{H}_{5}\right), 132.39\left(p-\mathrm{C}_{6} \mathrm{H}_{5}\right), 130.37(\mathrm{C} 3), 129.87\left(\mathrm{~d},{ }^{3} J_{\mathrm{PC}}=5.4 \mathrm{~Hz}\right.$, $\left.m-\mathrm{C}_{6} \mathrm{H}_{5}\right), 128.89(\mathrm{C} 5), 128.19\left(\mathrm{~d},{ }^{1} \mathrm{JPC}_{\mathrm{PC}}=28.8 \mathrm{~Hz}, i p s o-\mathrm{C}_{6} \mathrm{H}_{5}\right), 128.14(\mathrm{C} 4), 36.20\left(-\mathrm{CH}_{2} \mathrm{~N}-\right), 27.82(2 \mathrm{~d}$, $\left.J_{C-P}=16.9 \mathrm{~Hz},-\mathrm{CH}_{2} \mathrm{P}-\right) .{ }^{31} \mathrm{P}\left\{{ }^{1} \mathrm{H}\right\} \mathrm{NMR}\left(\mathrm{CD}_{2} \mathrm{Cl}_{2},-85^{\circ} \mathrm{C}\right) \delta(\mathrm{ppm}): 6.44\left(\mathrm{~d}, J_{P-A g}=527.1 \mathrm{~Hz}\right) .{ }^{19} \mathrm{~F} \mathrm{NMR}$ $\left(\mathrm{CDCl}_{3}\right) \delta(\mathrm{ppm}):-77.75$. MS $\left(\mathrm{MALDI}^{+}\right) \mathrm{m} / z:[\mathrm{M}]^{+} 787.2(100 \%) . \mathrm{C}_{39} \mathrm{H}_{36} \mathrm{AgF}_{5} \mathrm{~N}_{2} \mathrm{O}_{5} \mathrm{P}_{2} \mathrm{~S}_{3}$ (935.7) calcd. C 50.06, H 3.88, N 2.99, S 10.28; found C 49.98, H 4.01, N 2.92, S 9.90.

Synthesis of [Ag(OTf)L] (6): To a solution of $\mathbf{L}(0.15 \mathrm{mmol})$ in $\mathrm{CH}_{2} \mathrm{Cl}_{2}(20 \mathrm{~mL}), \mathrm{Ag}(\mathrm{OTf})(0.15 \mathrm{mmol})$ was added and the solution was stirred for $1 \mathrm{~h}$. Then the solution was evaporated to ca. $5 \mathrm{~mL}$ and addition of hexane $(15 \mathrm{~mL})$ led to a white solid. $62 \%$ yield. ${ }^{1} \mathrm{H} \mathrm{NMR}\left(\mathrm{CDCl}_{3}\right) \delta(\mathrm{ppm}): 7.82(\mathrm{~m}$, br, 1H, NH), 7.55 (m, br, 4H, Ph), 7.46 (m, br, 1H, H3), 7.35 (m, br, 7H, H5), 6.90 (m, 1H, H4), 3.76 $\left(\mathrm{m}, \mathrm{br}, 2 \mathrm{H},-\mathrm{CH}_{2} \mathrm{~N}-\right), 2.80\left(\mathrm{~m}, \mathrm{br}, 2 \mathrm{H},-\mathrm{CH}_{2} \mathrm{P}-\right) .{ }^{31} \mathrm{P}\left\{{ }^{1} \mathrm{H}\right\}$ NMR (Acetone- $\left.d_{6},-85{ }^{\circ} \mathrm{C}\right) \delta(\mathrm{ppm}): 3.27$ $\left(\mathrm{d}, J_{P-A g}=708.8 \mathrm{~Hz}\right) .{ }^{19} \mathrm{~F} \mathrm{NMR}\left(\mathrm{CDCl}_{3}\right) \delta(\mathrm{ppm}):-77.49 . \mathrm{C}_{20} \mathrm{H}_{18} \mathrm{AgF}_{5} \mathrm{NO}_{4} \mathrm{PS}_{2}$ (596.31) calcd. C 40.28, H 3.04, N 2.35, S 10.75; found C 40.15, H 3.16, N 2.42, S 11.04.

\subsection{General Procedure for the Synthesis of Phosphinegold(I) Thionucleobase Analogues 7-12}

A suspension of thionucleobase $(0.2 \mathrm{mmol})$ and $\mathrm{K}_{2} \mathrm{CO}_{3}(1 \mathrm{mmol})$ in $\mathrm{CH}_{2} \mathrm{Cl}_{2}(15 \mathrm{~mL})$ was stirred for 30 minutes. Then, the chlorophosphinegold(I) complex $(0.2 \mathrm{mmol})$ was added and the suspension was stirred overnight. The solution was filtrated and the solvent was evaporated until ca. $5 \mathrm{~mL}$ and added hexane $(15 \mathrm{~mL})$ to obtain a solid of the corresponding complex.

[Au(2-thiocytosine)L] (7): White solid, 60\% yield. ${ }^{1} \mathrm{H}$ NMR (Acetone- $\left.d_{6}\right) \delta(\mathrm{ppm}): 8.70$ (m, br, $1 \mathrm{H}$, $\mathrm{NH}), 7.92(\mathrm{~m}, 4 \mathrm{H}, \mathrm{Ph}), 7.76(\mathrm{~d}, J=5.77 \mathrm{~Hz}, 1 \mathrm{H}, \mathrm{H} 6), 7.60\left(\mathrm{~m}, 2 \mathrm{H}, \mathrm{H3}{ }^{\prime}, \mathrm{H}^{\prime}\right), 7.53(\mathrm{~m}, 6 \mathrm{H}, \mathrm{Ph}), 7.02(\mathrm{dd}$, $\left.J=5.0,3.8 \mathrm{~Hz}, 1 \mathrm{H}, \mathrm{H} 4^{\prime}\right), 6.13(\mathrm{~d}, J=5.79 \mathrm{~Hz}, 1 \mathrm{H}, \mathrm{H} 5), 5.93\left(\mathrm{~m}, \mathrm{br}, 2 \mathrm{H}, \mathrm{NH}_{2}\right), 3.79\left(\mathrm{~m}, 2 \mathrm{H},-\mathrm{CH}_{2} \mathrm{~N}-\right), 3.08$ $\left.\left(\mathrm{m}, 2 \mathrm{H},-\mathrm{CH}_{2} \mathrm{P}-\right) .{ }^{13} \mathrm{C}_{\{}{ }^{1} \mathrm{H}\right\}$ NMR (Acetone- $\left.d_{6}\right) \delta(\mathrm{ppm}): 163.89(\mathrm{C} 4), 162.58$ (C=O), $155.36(\mathrm{C} 6), 140.64$ $\left(\mathrm{C} 2^{\prime}\right), 134.29\left(\mathrm{~d},{ }^{2} J_{\mathrm{PC}}=13.6 \mathrm{~Hz}, o-\mathrm{C}_{6} \mathrm{H}_{5}\right), 132.47\left(\mathrm{~d},{ }^{4} J_{\mathrm{PC}}=2.3 \mathrm{~Hz}, p-\mathrm{C}_{6} \mathrm{H}_{5}\right), 131.85\left(\mathrm{~d},{ }^{1} J_{\mathrm{PC}}=55.1 \mathrm{~Hz}\right.$, ipso- $\left.\mathrm{C}_{6} \mathrm{H}_{5}\right), 131.05\left(\mathrm{C}^{\prime}\right), 130.12\left(\mathrm{~d}^{3}{ }^{3} \mathrm{PC}_{\mathrm{PC}}=11.3 \mathrm{~Hz}, \mathrm{~m}-\mathrm{C}_{6} \mathrm{H}_{5}\right), 128.86\left(\mathrm{C}^{\prime}\right), 128.35\left(\mathrm{C}^{\prime}\right), 100.70(\mathrm{C} 5), 37.37$ $\left(\mathrm{d}, J=7.8 \mathrm{~Hz},-\mathrm{CH}_{2} \mathrm{~N}-\right), 28.85\left(\mathrm{~d}, J=35.2 \mathrm{~Hz},-\mathrm{CH}_{2} \mathrm{P}-\right) .{ }^{31} \mathrm{P}\left\{{ }^{1} \mathrm{H}\right\} \mathrm{NMR}$ (Acetone- $\left.d_{6}\right) \delta(\mathrm{ppm}): 31.03$. MS $\left(\mathrm{ESI}^{+}\right) \mathrm{m} / \mathrm{z}:[\mathrm{M}]^{+} 663$ (100\%). $\mathrm{C}_{23} \mathrm{H}_{22} \mathrm{AuN}_{4} \mathrm{OPS}_{2}$ (662.5) calcd. C 41.69, H 3.35, N 8.46, S 9.68; found C 41.55, H 3.13, N 8.42, S 10.15.

[Au(2-thiopyridine)L] (8): Yellow solid, 55\% yield. ${ }^{1} \mathrm{H}$ NMR (Acetone- $\left.d_{6}\right) \delta(\mathrm{ppm}): 8.59(\mathrm{~m}, \mathrm{br}, 1 \mathrm{H}$, $\mathrm{NH}), 8.18(\mathrm{~d}, \mathrm{br}, J=5.0 \mathrm{~Hz}, 1 \mathrm{H}, \mathrm{H6}), 7.93(\mathrm{~m}, 4 \mathrm{H}, \mathrm{Ph}), 7.60(\mathrm{dd}, J=5.0,1.1 \mathrm{~Hz}, 1 \mathrm{H}, \mathrm{H} 4), 7.57(\mathrm{dd}, J=3.8$, $1.1 \mathrm{~Hz}, 1 \mathrm{H}, \mathrm{H} 3), 7.53$ (m, 6H, Ph), 7.38 (m, 2H, H5', H3'), 7.00 (dd, J = 5.0, 3.8 Hz, 1H, H5), 6.88 (td, $\left.\left.J=4.9,3.6 \mathrm{~Hz}, 1 \mathrm{H}, \mathrm{H} 4{ }^{\prime}\right), 3.79\left(\mathrm{~m}, 2 \mathrm{H},-\mathrm{CH}_{2} \mathrm{~N}-\right), 3.11\left(\mathrm{~m}, 2 \mathrm{H},-\mathrm{CH}_{2} \mathrm{P}-\right) .{ }^{13} \mathrm{C}^{1} \mathrm{H}\right\}$ NMR (Acetone- $d_{6}$ ) $\delta$ (ppm): 169.33 (C2), $162.50(\mathrm{C}=\mathrm{O}), 148.97$ (C6), 140.65 (C2'), 136.46 (C4), 134.28 (d, ${ }^{2} J_{\mathrm{PC}}=13.6 \mathrm{~Hz}$, $\left.o-\mathrm{C}_{6} \mathrm{H}_{5}\right), 132.52\left(\mathrm{~d},{ }^{4} \mathrm{JPC}_{\mathrm{PC}}=2.3 \mathrm{~Hz}, p-\mathrm{C}_{6} \mathrm{H}_{5}\right), 131.69\left(\mathrm{~d},{ }^{1} J_{\mathrm{PC}}=55.4 \mathrm{~Hz}\right.$, ipso- $\left.\mathrm{C}_{6} \mathrm{H}_{5}\right), 131.03\left(\mathrm{C}^{\prime}\right), 130.13$ $\left(\mathrm{d},{ }^{3} J_{\mathrm{PC}}=11.3 \mathrm{~Hz}, m-\mathrm{C}_{6} \mathrm{H}_{5}\right), 128.79\left(\mathrm{C}^{\prime}\right), 128.30\left(\mathrm{C}^{\prime}\right), 127.06(\mathrm{C} 5), 118.79(\mathrm{C} 3), 37.32(\mathrm{~d}, \mathrm{~J}=7.4 \mathrm{~Hz}$, $-\mathrm{CH}_{2} \mathrm{~N}-$ ), $28.72\left(\mathrm{~d}, J=35.3 \mathrm{~Hz},-\mathrm{CH}_{2} \mathrm{P}-\right.$ ). ${ }^{31} \mathrm{P}\left\{{ }^{1} \mathrm{H}\right\} \mathrm{NMR}$ (Acetone- $d_{6}$ ) $\delta(\mathrm{ppm}): 35.31 . \mathrm{C}_{24} \mathrm{H}_{22} \mathrm{AuN}_{2} \mathrm{OPS}_{2}$ (646.5) calcd. C 44.59, H 3.43, N 4.33, S 9.90; found C 44.65, H 3.28, N 4.34, S 9.93.

[Au(2-thiouracil)L] (9): White solid, 62\% yield. ${ }^{1} \mathrm{H}$ NMR $\left(\mathrm{CDCl}_{3}\right) \delta(\mathrm{ppm}): 8.70(\mathrm{~m}, \mathrm{br}, 1 \mathrm{H}, \mathrm{NH}), 7.63$ (m, 4H, Ph), $7.50\left(\mathrm{~m}, 2 \mathrm{H}, \mathrm{H} 6, \mathrm{H3} 3^{\prime}\right), 7.37$ (m, 7H, Ph, H5'), $6.92\left(\mathrm{dd}, J=5.0,3.8 \mathrm{~Hz}, 1 \mathrm{H}, \mathrm{H} 4^{\prime}\right), 6.05$ $\left.(\mathrm{d}, J=5.6 \mathrm{~Hz}, 1 \mathrm{H}, \mathrm{H} 5), 3.69\left(\mathrm{~m}, 2 \mathrm{H},-\mathrm{CH}_{2} \mathrm{~N}-\right), 2.88\left(\mathrm{~m}, 2 \mathrm{H},-\mathrm{CH}_{2} \mathrm{P}-\right) .{ }^{13} \mathrm{C}_{\{}^{1} \mathrm{H}\right\} \mathrm{NMR}\left(\mathrm{CDCl}_{3}\right) \delta(\mathrm{ppm})$ : $162.84(\mathrm{C}=\mathrm{O}), 138.84\left(\mathrm{C} 2^{\prime}\right), 133.24\left(\mathrm{~d},{ }^{2} J_{\mathrm{PC}}=13.4 \mathrm{~Hz}, o-\mathrm{C}_{6} \mathrm{H}_{5}\right), 131.85\left(p-\mathrm{C}_{6} \mathrm{H}_{5}\right), 130.26\left(\mathrm{C}^{\prime}\right), 129.64$ $\left(\mathrm{d},{ }^{1} J_{\mathrm{PC}}=57.4 \mathrm{~Hz}, i p s o-\mathrm{C}_{6} \mathrm{H}_{5}\right), 129.35\left(\mathrm{~d},{ }^{3} J_{\mathrm{PC}}=11.5 \mathrm{~Hz}, m-\mathrm{C}_{6} \mathrm{H}_{5}\right), 128.70\left(\mathrm{C}^{\prime}\right), 127.72\left(\mathrm{C}^{\prime}\right), 109.89$ (C5), $36.95\left(\mathrm{~d}, J=3.5 \mathrm{~Hz},-\mathrm{CH}_{2} \mathrm{~N}-\right), 28.72\left(\mathrm{~d}, J=36.8 \mathrm{~Hz},-\mathrm{CH}_{2} \mathrm{P}-\right) .{ }^{31} \mathrm{P}\left\{{ }^{1} \mathrm{H}\right\} \mathrm{NMR}\left(\mathrm{CDCl}_{3}\right) \delta(\mathrm{ppm}): 30.59$. MS $\left(\mathrm{ESI}^{+}\right) \mathrm{m} / z$ : $[\mathrm{M}]^{+} 663.8$ (38.34\%). $\mathrm{C}_{23} \mathrm{H}_{21} \mathrm{AuN}_{3} \mathrm{O}_{2} \mathrm{PS}_{2}$ (663.5) calcd. C 41.63, H 3.19, N 6.33, S 9.67; found C 41.55, H 3.18, N 6.50, S 10.11.

[Au(2-thionicotinic acid)L] (10): Yellow solid, 57\% yield. ${ }^{1} \mathrm{H} \mathrm{NMR}\left(\mathrm{CDCl}_{3}\right) \delta$ (ppm): 9.36 (m, br, $1 \mathrm{H}$, $\mathrm{OH}), 7.70-7.00$ (m, 14H, Ph, H6, H4, H5, H3' $\left.\mathrm{H}^{\prime}{ }^{\prime}\right), 6.72$ (m, br, 1H, H4'), 6.31 (m, br, 1H, NH), 3.50-3.45 $\left(\mathrm{m}, 2 \mathrm{H},-\mathrm{CH}_{2} \mathrm{~N}-\right), 2.56\left(\mathrm{~m}, \mathrm{br}, 2 \mathrm{H},-\mathrm{CH}_{2} \mathrm{P}-\right) .{ }^{31} \mathrm{P}\left\{{ }^{1} \mathrm{H}\right\} \mathrm{NMR}\left(\mathrm{CDCl}_{3}\right) \delta(\mathrm{ppm}): 28.91$. MS $\left(\mathrm{ESI}^{+}\right) \mathrm{m} / \mathrm{z}:[\mathrm{M}]^{+}$ 
691 (100\%). $\mathrm{C}_{25} \mathrm{H}_{22} \mathrm{AuN}_{2} \mathrm{O}_{3} \mathrm{PS}_{2}$ (690.1) calcd. C 43.48, H 3.21, N 4.06, S 9.27; found C 43.52, H 3.03, N 3.93, S 8.55.

[Au(thioglucose)L] (11): White solid, 65\% yield. ${ }^{1} \mathrm{H}$ NMR (Acetone- $\left.d_{6}\right) \delta(\mathrm{ppm}): 7.94(\mathrm{~m}, 5 \mathrm{H}, \mathrm{Ph}, \mathrm{NH})$, $7.64\left(\mathrm{dd}, J=5.0,1.0 \mathrm{~Hz}, 1 \mathrm{H}, \mathrm{H3} 3^{\prime}\right), 7.55\left(\mathrm{~m}, 7 \mathrm{H}, \mathrm{Ph}, \mathrm{H}^{\prime}\right), 7.07\left(\mathrm{dd}, J=5.0,3.8 \mathrm{~Hz}, 1 \mathrm{H}, \mathrm{H} 4^{\prime}\right), 5.18(\mathrm{t}$, $J=9.4 \mathrm{~Hz}, 1 \mathrm{H}, \mathrm{H} 5), 5.07(\mathrm{t}, J=9.7 \mathrm{~Hz}, 1 \mathrm{H}, \mathrm{H} 4), 5.00(\mathrm{~m}, 2 \mathrm{H}, \mathrm{H6}, \mathrm{H} 1), 4.24(\mathrm{dd}, J=12.3,4.8 \mathrm{~Hz}, 1 \mathrm{H}$, $\left.-\mathrm{CH}_{2}-\right), 4.09\left(\mathrm{dd}, J=12.3,2.2 \mathrm{~Hz}, 1 \mathrm{H},-\mathrm{CH}_{2}-\right), 3.92(\mathrm{~m}, \mathrm{br}, 1 \mathrm{H}, \mathrm{H} 3), 3.77\left(\mathrm{~m}, 2 \mathrm{H},-\mathrm{CH}_{2} \mathrm{~N}-\right), 3.17(\mathrm{~m}, 1 \mathrm{H}$, $\left.-\mathrm{CH}_{2} \mathrm{P}-\right), 3.00\left(\mathrm{~m}, 1 \mathrm{H},-\mathrm{CH}_{2} \mathrm{P}-\right), 1.98\left(\mathrm{~s}, 6 \mathrm{H},-\mathrm{COCH}_{3}\right), 1.91\left(\mathrm{~s}, 6 \mathrm{H},-\mathrm{COCH}_{3}\right) .{ }^{13} \mathrm{C}\left\{{ }^{1} \mathrm{H}\right\} \mathrm{NMR}\left(\mathrm{CDCl}_{3}\right)$ $\delta$ (ppm): 170.29, $169.69(\mathrm{O}-\mathrm{C}=\mathrm{O}), 162.50(\mathrm{~N}-\mathrm{C}=\mathrm{O}), 138.80\left(\mathrm{C}^{\prime}\right), 133.49\left(\mathrm{~d},{ }^{2} \mathrm{~J}_{\mathrm{PC}}=13.6 \mathrm{~Hz}, o-\mathrm{C}_{6} \mathrm{H}_{5}\right)$, $133.11\left(\mathrm{~d},{ }^{2} J_{\mathrm{PC}}=13.4 \mathrm{~Hz}, o-\mathrm{C}_{6} \mathrm{H}_{5}\right), 131.73\left(\mathrm{~d},{ }^{4} J_{\mathrm{PC}}=2.5 \mathrm{~Hz}, p-\mathrm{C}_{6} \mathrm{H}_{5}\right), 131.65\left(\mathrm{~d},{ }^{4} J_{\mathrm{PC}}=2.5 \mathrm{~Hz}, p-\mathrm{C}_{6} \mathrm{H}_{5}\right)$, $130.37\left(\mathrm{~d},{ }^{1} J_{P C}=55.4 \mathrm{~Hz}\right.$, ipso- $\left.\mathrm{C}_{6} \mathrm{H}_{5}\right), 130.21\left(\mathrm{C} 3^{\prime}\right), 130.04\left(\mathrm{~d},{ }^{1} J_{P C}=55.6 \mathrm{~Hz}\right.$, ipso- $\left.\mathrm{C}_{6} \mathrm{H}_{5}\right), 129.43(\mathrm{~d}$, $\left.{ }^{3} J_{\mathrm{PC}}=5.9 \mathrm{~Hz}, o-\mathrm{C}_{6} \mathrm{H}_{5}\right), 129.28\left(\mathrm{~d}^{3}{ }^{3} \mathrm{PC}_{\mathrm{PC}}=5.9 \mathrm{~Hz}, m-\mathrm{C}_{6} \mathrm{H}_{5}\right), 128.24\left(\mathrm{C}^{\prime}\right), 127.43\left(\mathrm{C} 4^{\prime}\right), 76.16(\mathrm{C} 3), 74.29$ $(\mathrm{C} 5, \mathrm{C} 6, \mathrm{C} 1), 68.84(\mathrm{C} 4), 62.60\left(-\mathrm{CH}_{2}-\right), 37.66\left(\mathrm{~d}, J=4.6 \mathrm{~Hz},-\mathrm{CH}_{2} \mathrm{~N}-\right), 28.10\left(\mathrm{~d}, J=34.9 \mathrm{~Hz},-\mathrm{CH}_{2} \mathrm{P}-\right)$, 21.42, $20.77\left(\mathrm{CH}_{3}-\mathrm{COOCH}_{2}\right) .{ }^{31} \mathrm{P}\left\{{ }^{1} \mathrm{H}\right\}$ NMR (Acetone- $\left.d_{6}\right) \delta(\mathrm{ppm}): 31.49 . \mathrm{MS}\left(\mathrm{ESI}^{+}\right) \mathrm{m} / z:[\mathrm{M}]^{+} 900.3$ (45.70\%). $\mathrm{C}_{33} \mathrm{H}_{37} \mathrm{AuNO}_{10} \mathrm{PS}_{2}$ (899.7) calcd. C 44.04, $\mathrm{H} 4.15, \mathrm{~N} 1.56, \mathrm{~S} 7.13$; found C 43.96, H 4.14, N 1.47, S 6.99 .

[Au(6-thiopurine)L] (12): White solid, 57\% yield. ${ }^{1} \mathrm{H}$ NMR (Acetone- $\left.d_{6}\right) \delta(\mathrm{ppm}): 9.77(\mathrm{~m}, \mathrm{br}, 1 \mathrm{H}$, $\mathrm{NH}), 8.34$ (s, 1H, H9), 8.03 (s, 1H, H5), 7.96 (m, 4H, Ph), 7.50 (m, 8H, Ph, H5', NH, H3'), 6.79 (dd, $\left.\left.J=4.9,3.8 \mathrm{~Hz}, 1 \mathrm{H}, \mathrm{H} 4^{\prime}\right), 3.84\left(\mathrm{~m}, 2 \mathrm{H},-\mathrm{CH}_{2} \mathrm{~N}-\right), 3.08\left(\mathrm{~m}, 2 \mathrm{H},-\mathrm{CH}_{2} \mathrm{P}-\right) .{ }^{13} \mathrm{C}_{1}{ }^{1} \mathrm{H}\right\}$ NMR (Acetone- $d_{6}$ ) $\delta$ (ppm): $162.55(\mathrm{C}=\mathrm{O}), 134.31\left(\mathrm{~d},{ }^{2} J_{P C}=11.5 \mathrm{~Hz}, o-\mathrm{C}_{6} \mathrm{H}_{5}\right), 132.36\left(\mathrm{~s}, p-\mathrm{C}_{6} \mathrm{H}_{5}\right), 130.23\left(\mathrm{C}^{\prime}\right), 130.06$ $\left(\mathrm{d},{ }^{3} J_{P C}=9.4 \mathrm{~Hz}, m-\mathrm{C}_{6} \mathrm{H}_{5}\right), 129.91\left(\mathrm{C}^{\prime}\right), 128.51\left(\mathrm{C}^{\prime}\right) .{ }^{31} \mathrm{P}\left\{{ }^{1} \mathrm{H}\right\}$ NMR (Acetone- $\left.d_{6}\right) \delta(\mathrm{ppm}): 26.82 . \mathrm{MS}$ $\left(\mathrm{ESI}^{+}\right) \mathrm{m} / z:[\mathrm{M}]^{+} 691$ (100\%). $\mathrm{C}_{24} \mathrm{H}_{21} \mathrm{AuN}_{5} \mathrm{OPS}_{2}$ (687.1) calcd. C 41.93, H 3.08, N 10.17, S 9.33; found C 42.24, H 3.12, N 9.71, S 8.55.

\subsection{Cristallography}

Crystals were mounted in inert oil on glass fibers and transferred to the cold gas stream of Xcalibur Oxford Diffraction $(3,6)$ or a SMART Apex CCD (7) diffractometer equipped with a low-temperature attachment. Data were collected using monochromated Mo K $\alpha$ radiation $(\lambda=0.71073 \AA)$. Scan type $\omega$. Absorption correction based on multiple scans was applied using spherical harmonics implemented in SCALE3 ABSPACK [35] scaling algorithm or SADABS. The structures were solved by direct methods and refined on $F^{2}$ using the program SHELX [36]. All non-hydrogen atoms were refined anisotropically, with the exception of some solvent atoms. Refinements were carried out by full-matrix least-squares on $F^{2}$ for all data. CCDC 1881668 (6), 1881669 (7) and 1881670 (3) contains the Supplementary crystallographic data for this paper. These data can be obtained free of charge from The Cambridge Crystallographic Data Centre via www.ccdc.cam.ac.uk/data_request/cif.

\subsection{Cell Culture}

HEP-G2 cells (human hepatocellular carcinoma cells), NIH-3T3 cells (mouse fibroblasts), A-549 cells (human lung carcinoma cells), and PC12 (pheochromocytoma of the rat adrenal medulla). All cell lines were cultivated in Dulbecco's Modified Eagle's medium (DMEM, D7777 Sigma-Aldrich, Madrid, Spain) supplemented with with $10 \%$ fetal bovine serum (FBS) and $1 \%$ antibiotics (penicillin/ $100 \mathrm{U} / \mathrm{mL}$ and streptomycin/ $100 \mu \mathrm{g} / \mathrm{mL}$ ) in a humidified environment at $37^{\circ} \mathrm{C} / 5 \% \mathrm{CO}_{2}$. After three to four days the cells were then detached with trypsin and cultured in another cell culture flask. Wells of a 96 well plate were seeded with the cells and incubated for three days. At day 4 the medium of each well was removed and $200 \mu \mathrm{L}$ of the gold and silver complexes in different concentrations in the cell culture medium were added to the wells $(1-100 \mu \mathrm{M})$. The cells were cultivated for two additional days and then, the viability of the cells was determined by the MTT-assay. 


\subsection{Cytotoxicity MTT Assay}

The MTT assay was used to calculate cell viability. Exponentially growing cells were seeded at a density of $\sim 4 \times 10^{5}$ cells $/ \mathrm{mL}$, in a 96-well microplate, and $48 \mathrm{~h}$ later they were incubated with the complexes. The compounds were dissolved in DMSO and tested in concentrations ranging from 1 to $100 \mu \mathrm{M}$.

Cytotoxicity of tested compounds was evaluated by the MTT method [37]. The optical density was measured at $570 \mathrm{~nm}$ using a 96-well multiscanner autoreader. The $\mathrm{IC}_{50}$ values were calculated by non-linear regression analysis using Origin software (Origin Software, Electronic Arts, Redwood City, CA, USA)

\section{Conclusions}

A new amidophosphine ligand bearing a thiophene moiety has been synthesized and the coordination behaviour towards gold and silver complexes has been studied. The coordination of the gold(I/III) or silver(I) fragments takes place through the phosphorus atom. In contrast for the silver species coordination to the phosphorus atom together with the oxygen atoms of the carbonyl and triflate groups is observed. The crystal structures of some of these derivatives present supramolecular structures through hydrogen bonding. Cytotoxicity studies in several cancer lines, such as A-549, Hep-G2 or NIH-3T3 and PC-12 have been performed for the ligand and all the synthesized complexes, showing that whereas the thiophene amidophosphine lacks activity, the gold and silver complexes exhibit moderate to excellent activities in all the cell lines. From the structure activity relationship perspective is possible to conclude that the best activities are achieved with the cationic bis(amidophosphine) species and with the thiolate derived from the 2,3,4,6-tetra-6-acetyl-1-thiol- $\beta$-D-glucopyranosato ligand. In general, gold complexes are more cytotoxic than the silver ones, with the exception of the A-549 cell line. The cytotoxicity values are much better than those exhibited by cisplatin.

Supplementary Materials: The following are available online at http:/ /www.mdpi.com/2304-6740/7/2/13/s1, CIF and checkCIF files.

Author Contributions: Conceptualization, M.C.G. and A.L.; methodology, H.G.; software, H.G. and M.D.V.; formal analysis, H.G.; investigation, H.G.; writing-original draft preparation, M.C.G. and M.D.V.; writing-review and editing, M.C.G., M.D.V. and A.L.; project administration, M.C.G.; funding acquisition, M.C.G.

Funding: This research was funded by Ministerio de Ciencia, Innovación y Universidades, grant number CTQ2016-75816-C2-1-P and and Gobierno de Aragón-Fondo Social Europeo, grant number E07_17R.

Acknowledgments: The authors thank the Ministerio de Ciencia, Innovación y Universidades (CTQ2016-75816-C2-1-P) and Gobierno de Aragón-Fondo Social Europeo (E07_17R) for financial support.

Conflicts of Interest: The authors declare no conflict of interest.

\section{References}

1. Rosenberg, B.; VanCamp, L.; Trosko, J.E.; Monsour, V.H. Platinum Compounds: A New Class of Potent Antitumour Agents. Nature 1969, 222, 385-386. [CrossRef]

2. Lippert, B. Cisplatin: Chemistry and Biochemistry of a Leading Anticancer Drug; Wiley-VCH: Weinheim, Germany, 1999.

3. Johnstone, T.C.; Suntharalingam, K.; Lippard, S.J. The Next Generation of Platinum Drugs: Targeted Pt(II) Agents, Nanoparticle Delivery, and Pt(IV) Prodrugs. Chem. Rev. 2016, 116, 3436-3486. [CrossRef]

4. Bergamo, A.; Sava, G. Ruthenium anticancer compounds: Myths and realities of the emerging metal-based drugs. Dalton Trans. 2011, 40,7817-7823. [CrossRef]

5. Phase I and II Study of Auranofin in Chronic Lymphocytic Leukemia (CLL). Available online: https: / / clinicaltrials.gov / ct2/show / NCT01419691 (accessed on 2 September 2018).

6. Ott, I. On the medicinal chemistry of gold complexes as anticancer drugs. Coord. Chem. Rev. 2009, 253, 1670-1681. [CrossRef] 
7. Nobili, S.; Mini, E.; Landini, I.; Gabbiani, C.; Casini, A.; Messori, L. Gold compounds as anticancer agents: Chemistry, cellular pharmacology, and preclinical studies. Med. Res. Rev. 2010, 30, 550-580. [CrossRef]

8. Bertrand, B.B.; Casini, A. A golden future in medicinal inorganic chemistry: The promise of anticancer gold organometallic compounds. Dalton Trans. 2014, 43, 4209-4219. [CrossRef]

9. Zou, T.; Lum, C.T.; Lok, C.-N.; Zhang, J.-J.; Che, C.M. Chemical biology of anticancer gold(III) and gold(I) complexes. Chem. Soc. Rev. 2015, 44, 8786-8801. [CrossRef]

10. Barnard, P.T.; Berners-Price, S.J. Targeting the mitochondrial cell death pathway with gold compounds. Coord. Chem. Rev. 2007, 251, 1889-1902. [CrossRef]

11. Bindoli, A.; Rigobello, M.P.; Scutari, G.; Gabbiani, C.; Casini, A.; Messori, L. Thioredoxin reductase: A target for gold compounds acting as potential anticancer drugs. Coord. Chem. Rev. 2009, 253, 1692-1707. [CrossRef]

12. Dalla Via, L.; Nardon, C.; Fregona, D. Targeting the ubiquitin-proteasome pathway with inorganic compounds to fight cancer: A challenge for the future. Future Med. Chem. 2012, 4, 525-543. [CrossRef]

13. Baumann, M.; Baxendale, I.R.; Ley, S.V.; Nikbin, N. An overview of the key routes to the best selling 5-membered ring heterocyclic pharmaceuticals. Beilstein J. Org. Chem. 2011, 7, 442-495. [CrossRef]

14. Hartman, H.B.; Roehr, J.E.; Rogers, K.L.; Rush, D.K.; Szczepanik, A.M.; Szewczak, M.R.; Wilmot, C.A.; Conway, P.G. 3[4-[1-(6-Fluorobenzo[b]thiophen-3-yl)-4-piperazinyl]butyl]-2,5,5-trimethyl-4-thiazolidinone: A new atypical antipsychotic agent for the treatment of schizophrenia. J. Med. Chem. 1992, 35, 2712-2715.

15. Bohlman, F.; Zdero, C. Thiophene and Its Derivatives; Gronowitz, S., Ed.; John Wiley \& Sons, Ltd.: Chichester, UK, 1986; Part 3, pp. 261-323.

16. Hafez, H.N.; El-Gazzar, A.B.A. Design and synthesis of 3-pyrazolyl-thiophene, thieno[2,3-d]pyrimidines as new bioactive and pharmacological activities. Bioorg. Med. Chem. Lett. 2008, 18, 5222-5227. [CrossRef]

17. Vogel, V.G.; Costantino, J.P.; Wickerham, D.L.; Cronin, W.M.; Cecchini, R.S.; Atkins, J.N.; Bevers, T.B.; Fehrenbacher, L.; Pajon, E.R., Jr.; Wade, J.L., III; et al. Effects of tamoxifen vs raloxifene on the risk of developing invasive breast cancer and other disease outcomes: The NSABP Study of Tamoxifen and Raloxifene (STAR) P-2 trial. J. Am. Med. Assoc. 2006, 295, 2727-2741. [CrossRef]

18. Chakrabarti, J.K.; Hotten, T.M.; Tupper, D.E. 2-Methylthienobenzodiazepine. U.S. Patent 5,627,178, 6 May 1997.

19. Wang, L.; Shen, J.; Tang, Y.; Chen, Y.; Wang, W.; Cai, Z.; Du, Z. Synthetic Improvements in the Preparation of Clopidogrel. Org. Process Res. Dev. 2007, 11, 487-489. [CrossRef]

20. Gimeno, M.C.; Goitia, H.; Laguna, A.; Luque, M.E.; Villacampa, M.D.; Sepúlveda, C.; Meireles, M. Conjugates of ferrocene with biological compounds. Coordination to gold complexes and antitumoral properties. J. Inorg. Biochem. 2011, 105, 1373-1382. [CrossRef]

21. Goitia, H.; Nieto, Y.; Villacampa, M.D.; Kasper, C.; Laguna, A.; Gimeno, M.C. Antitumoral Gold and Silver Complexes with Ferrocenyl-Amide Phosphines. Organometallics 2013, 32, 6069-6078. [CrossRef]

22. Gutiérrez, A.; Gracia-Fleta, L.; Marzo, I.; Cativiela, C.; Laguna, A.; Gimeno, M.C. Gold(I) thiolates containing amino acid moieties. Cytotoxicity and structure-activity relationship studies. Dalton Trans. 2014, 43, 17054-17066. [CrossRef]

23. Gutiérrez, A.; Marzo, I.; Cativiela, C.; Laguna, A.; Gimeno, M.C. Highly Cytotoxic Bioconjugated Gold(I) Complexes with Cysteine-Containing Dipeptides. Chem. Eur. J. 2015, 21, 11088-11095. [CrossRef]

24. Ortego, L.; Meireles, M.; Kasper, C.; Laguna, A.; Villacampa, M.D.; Gimeno, M.C. Group 11 complexes with amino acid derivatives: Synthesis and antitumoral studies. J. Inorg. Biochem. 2016, 156, 133-144. [CrossRef]

25. Bardají, M.; Jones, P.G.; Laguna, A.; Villacampa, M.D.; Villaverde, N. Synthesis and Structural Characterization of Luminescent Gold(I) Derivatives with an Unsymmetric Diphosphine. Dalton Trans. 2003, 23, 4529-4536. [CrossRef]

26. Fillat, M.F.; Gimeno, M.C.; Laguna, A.; Latorre, E.; Ortego, L.; Villacampa, M.D. Synthesis, structure and bactericide activity of (aminophosphane)gold(I) thiolate complexes. Eur. J. Inorg. Chem. 2011, 9, 1487-1495. [CrossRef]

27. Artigas, M.M.; Crespo, O.; Gimeno, M.C.; Jones, P.G.; Laguna, A.; Villacampa, M.D. Synthesis and characterization of $\left[\mathrm{Ag}_{4}\left(\mu_{3}-\mathrm{SC}_{2} \mathrm{~B}_{10} \mathrm{H}_{11}\right)_{2}\left(\mu-\mathrm{O}_{3} \mathrm{SCF}_{3}\right)_{2}\left(\mathrm{PPh}_{3}\right)_{4}\right]$ : A silver complex with a $\mu_{3}$-thiolate ligand. Inorg. Chem. 1997, 36, 6454-6456. [CrossRef]

28. Bardají, M.; Crespo, O.; Laguna, A.; Fischer, A.K. Structural characterization of silver(I) complexes $\left[\mathrm{Ag}\left(\mathrm{O}_{3} \mathrm{SCF}_{3}\right)(\mathrm{L})\right]\left(\mathrm{L}=\mathrm{PPh}_{3}, \mathrm{PPh}_{2} \mathrm{Me}, \mathrm{SC}_{4} \mathrm{H}_{8}\right)$ and $\left[\mathrm{AgL}_{n}\right]\left(\mathrm{CF}_{3} \mathrm{SO}_{3}\right)(n=2-4),\left(\mathrm{L}=\mathrm{PPh}_{3}, \mathrm{PPh}_{2} \mathrm{Me}\right)$. Inorg. Chim. Acta 2000, 304, 7-16. [CrossRef] 
29. Zhang, P.; Gao, W.Y.; Turner, S.; Ducatman, B.S. Gleevec (STI-571) inhibits lung cancer cell growth (A549) and potentiates the cisplatin effect in vitro. Mol. Cancer 2003, 2, 1. [CrossRef]

30. Shao, J.; Ma, Z.-Y.; Li, A.; Liu, Y.-H.; Xie, C.-Z.; Qiang, Z.-Y.; Xu, J.-Y. Thiosemicarbazone Cu(II) and Zn(II) complexes as potential anticancer agents: Syntheses, crystal structure, DNA cleavage, cytotoxicity and apoptosis induction activity. J. Inorg. Biochem. 2014, 136, 13-23. [CrossRef]

31. Suntharalingam, K.; Mendoza, O.; Duarte, A.A.; Mann, D.J.; Vilar, R. A platinum complex that binds non-covalently to DNA and induces cell death via a different mechanism than cisplatin. Metallomics 2013, 5, 514-523. [CrossRef]

32. Usón, R.; Laguna, A. Polyaryl Derivatives of Gold(I), Silver(I) and Gold(III). In Organometallic Syntheses; King, R.B., Eisch, J.J., Eds.; Elsevier: Amsterdam, The Netherlands, 1986; Volume 3, pp. 322-342.

33. Usón, R.; Laguna, A.; Navarro, A.; Parish, R.V.; Moore, L.S. Synthesis and reactivity of perchlorate bis(tetrahydrothiophen)gold(I). ${ }^{197} \mathrm{Au}$ Mössbauer spectra of three-coordinate gold(I) complexes. Inorg. Chim. Acta 1986, 112, 205-208. [CrossRef]

34. Usón, R.; Laguna, A.; Laguna, M.; Jiménez, J.; Gómez, M.P.; Sainz, A.; Jones, P.G. Gold complexes with heterocyclic thiones as ligands. X-Ray structure determination of $\left[\mathrm{Au}\left(\mathrm{C}_{5} \mathrm{H}_{5} \mathrm{NS}\right)_{2}\right] \mathrm{ClO}_{4}$. J. Chem. Soc. Dalton Trans. 1990, 3457-3463. [CrossRef]

35. CrysAlisPro, Version 1.171.35.11; Agilent Technologies: Yarnton, UK, 2011.

36. Sheldrick, G.M. Crystal structure refinement with SHELXL. Acta Cryst. 2015, C71, 3-8.

37. Mosmann, T.J. Rapid colorimetric assay for cellular growth and survival: Application to proliferation and cytotoxicity assays. Immunol. Methods 1983, 65, 55-63. [CrossRef]

(C) 2019 by the authors. Licensee MDPI, Basel, Switzerland. This article is an open access article distributed under the terms and conditions of the Creative Commons Attribution (CC BY) license (http:/ / creativecommons.org/licenses/by/4.0/). 